Article

\title{
Assessing a Nation's Competitiveness in Global Food Innovation: Creating a Global Food Innovation Index
}

\author{
Sylvain Charlebois*D, Amy Hill, Janèle Vezeau, Lydia Hunsberger, Maddy Johnston and Janet Music
}

Agri-Food Analytics Lab, Dalhousie University, 6100 University Avenue, Halifax, NS B3H 4R2, Canada; amy.hill@dal.ca (A.H.); janele.vezeau@cafi-icpa.ca (J.V.); lydia.hunsberger@gmail.com (L.H.); md574006@dal.ca (M.J.); janet.music@dal.ca (J.M.)

* Correspondence: sylvain.charlebois@dal.ca

Citation: Charlebois, S.; Hill, A.; Vezeau, J.; Hunsberger, L.; Johnston, M.; Music, J. Assessing a Nation's Competitiveness in Global Food Innovation: Creating a Global Food Innovation Index. World 2022, 3, 27-66. https://doi.org/ 10.3390 /world3010002

Academic Editor: Mario D’Amico

Received: 28 November 2021 Accepted: 30 December 2021 Published: 12 January 2022

Publisher's Note: MDPI stays neutral with regard to jurisdictional claims in published maps and institutional affiliations.

Copyright: (C) 2022 by the authors. Licensee MDPI, Basel, Switzerland. This article is an open access article distributed under the terms and conditions of the Creative Commons Attribution (CC BY) license (https:// creativecommons.org/licenses/by/ $4.0 /)$.

\begin{abstract}
While food innovation is heavily influenced by the myriad of policies, regulations and other environmental factors within a country, globalization means that food innovation is also a matter of international competitiveness. This benchmarking exercise uses 24 variables to compare the different innovation environments across ten countries: Canada, the US, Mexico, the UK, France, Germany, Italy, the Netherlands, Japan, and Australia. Quantitative and qualitative data was collected from publicly available sources only to measure each variable and ultimately provide a ranking. Qualitative data was evaluated using thematic coding to establish baseline practices and then compare each country to the baseline. Quantitative data was evaluated by constructing an average to which each country was compared. Countries whose data showed they met the average were awarded two points, and those who performed above or below average were either awarded an additional point or saw a point deducted. A final ranking was established from the scores across all four pillars, and the ranking was weighted to account for lacking data. The final weighted ranking saw the UK rank first, followed by the US, Germany, Australia, Canada, the Netherlands, Japan, Mexico, France and finally, Italy in tenth place.
\end{abstract}

Keywords: food innovation; innovation policy; food innovation index; international food innovation

\section{Introduction}

Food innovation refers to the development of existing products and processes or the creation of new products and processes in the food supply chain. While food innovation is undertaken mostly by food suppliers and manufacturers, it is also important to consumers and the overall food supply market. Adapting to new environments and markets allows for the agri-food sector to remain relevant and grow over time. Innovations in agrifood are an essential part of the further advancement of societies in general as well as of companies. Individuals can benefit from the advantages of food innovations, while businesses can maintain or increase their influence and profitability. A more innovative environment benefits both consumers and suppliers. Innovation spurs competition and generally increases consumer choice, thereby increasing consumer welfare. Innovation, on the supply side, leads to new and often more efficient technologies which benefit suppliers. The myriad of policies, regulations, other government actions and other environmental factors in a country can either spur that innovation or hinder it, affecting both consumers and suppliers in the market for food.

Literature in the food innovation policy space often focuses on specific areas of the industry, for example farming [1], manufacturing and processing [2], retail [3], academia [4], or particular products or technologies [5-7]. Literature in food innovation policy also focuses on different perspectives, such as the consumer [8], or particular governments or regions $[9,10]$. Such a topic warrants a broader view as food innovation policies impact a complex system, and this is demonstrated through the vast and varied literature. While 
there are many accounts of these different areas and complexities, there does not appear to be a focus looking at both ends of the food continuum. A benchmarking exercise which attempts to account for then compare and rank different food innovation policy environments across countries would be beneficial to both industry and governments. There is a need for a better understanding of innovation in the food industry-known as a relatively conservative, mature and slow-growing business sector-which can foster more collaboration with industry and between nations. All face similar challenges such as climate change and global economy challenges by severe unpredictable market condition shifts.

Both the food safety and health disciplines have expanded their use of benchmarking to compare countries and provide a measure of performance, but this method does not appear to have been used in the food innovation policy context, which is a missed opportunity [11-14]. Countries may have their own challenges and strengths, but this does not mean that they cannot apply successful policy ideas from other countries. Implementing and learning from successful policies in other countries is also a means of creating efficiency and generating cost savings in the policy process. In order to do this, however, countries need to be able to identify successful policies, regulations or laws. This paper aims to assist countries in this exercise of learning from and identifying successful measures in other countries to improve the food innovation environment.

This benchmarking exercise compares food innovation environments across ten countries: Canada; the US; Mexico; the UK; France; Germany; Italy; the Netherlands; Japan; and Australia. To compare food innovation environments, this paper uses a model consisting of 24 indicators divided across four pillars, including the Regulatory Environment, Business Competitiveness, Market Readiness, and Intellectual Property and Research and Development. The 24 indicators were chosen to reflect not only the experiences of different players in the food market from workers to consumers, but also the different external factors which impact the food innovation environment such as a country's economy, laws and regulations. Almost 400 data points were collected from public sources to examine each of the ten countries' food innovation environments. While this paper concludes with an overall ranking for each country, there are scores and justifications provided for each country for all 24 indicators. Detailed, specific analyses on different policies, regulations, laws and other government actions are important to this research so that there are not only specific examples to inform scores, but also so that this research can be used by policy makers designing food innovation policies across the world.

\section{Methods and Limitations}

\subsection{Benchmarking as the Chosen Methodology}

Other methods could have been considered but the intent for this study was to empower nations to compare performances so more sharing of data and knowledge between nations can occur. Perhaps the most important benefit we can learn from international comparisons is that strong performance and improvement are always possible. The successes of other nations can provide potential guidance for decision making in Canada and elsewhere. One of the main ways to identify high-performing food innovation systems is through international assessments and benchmarking reports such as this one.

As the introduction notes, benchmarking as a tool to compare policies and practices has been increasingly used in the food safety and health disciplines [11-14]. Benchmarking allows researchers to evaluate policies or practices in relation to each other-it is inherently comparative. The primary aim of this paper is for countries to improve their food innovation policies, where needed, by learning from the policies of others, which is a comparative exercise. Benchmarking in this paper also allows the researchers to examine and compare policies, without a need to identify an ideal policy stance as the comparator policy. Instead, countries are benchmarked against the policies of other countries. While this type of analysis may not imagine new ways of creating food innovation policy, the analysis reflects the realities of what is possible in the food innovation policy sphere. 
To define the framework and indicators, the team met with some experts in Canada to gather their views on the most important indicators for food innovation. In addition, the team contacted several trade groups and associations which represented different nodes within the food supply chain. Indicators developed for the framework focused primarily on managerial and policy information and subsequently on quality information, but quality for such a breadth and international survey is only available at an aggregate level.

\subsection{Creation of Pillars}

The indicators and resulting pillars for this study were carefully chosen to address the complex environment in which food innovation policy occurs and to provide concrete, useful solutions for policy makers. All indicators were approved by Innovation, Science and Economic Development Canada. Pillar 1, Regulatory Environment, focuses on regulations and laws, considering both the environment for creating products as well as restrictions with regard to waste and protection of the environment. Pillar 2, Business Competitiveness, uses macro- and micro-economic indicators to account for the economic context, while also examining investments, government support and the retail environment. Pillar 3, Market Readiness, considers how countries create a labour force that is equipped to participate in food innovation through policies affecting education, and diversity and inclusion. Finally, Pillar 4, Intellectual Property and Research and Development, accounts for the protections afforded to innovations as well as supports for innovation in fiscal policies. Descriptions of the four main pillars and indicators can be found in Appendices A-D.

\subsection{Weighting of Variables}

Each pillar is assigned a weighting, based on the number of sub-pillars and on the number of criteria within each sub-pillar (see Figure 1). For instance, Section 1 is worth 15 points, based on the three criteria in Section 1.1, each worth three points $(3 \times 3=9)$ and the two criteria in Section 1.2 , also worth three points $(3 \times 2=6)$. The weighting across the pillars is largely reflective of the number of indicators in each pillar because each indicator has the same maximum number of points which can be awarded ( 3 points). The scores within a pillar help countries identify where their policies may have shortfalls compared to others based on scores but, as a whole, the index is skewed by the significant number of variables in Pillar 2, Business Competitiveness. External economics and the grocery industry, both of which are accounted for by the indicators in Pillar 2, do however play an important role in the food innovation environment. Future research may consider a re-weighting of the variables and also the pillars. In this paper, the identical maximum score of three points allowed for consistent data collection and analysis methods which are explained below.

Scores were calculated using whole points, and final performance ratings were based on a country's score within a pillar and overall score aggregating all four pillars. Scores of zero were only applicable when the researchers identified a lack of data or encountered restrictions that prevented access. A value of N/A was given when data may exist, but researchers could not access it due to language barriers. 


\begin{tabular}{|c|c|c|c|}
\hline $\begin{array}{c}\text { Pillar } 1 \\
\text { Regulatory } \\
\text { Environment } \\
\text { (15) }\end{array}$ & $\begin{array}{c}\text { Pillar } 2 \\
\text { Business } \\
\text { Competitiveness } \\
\text { (24) }\end{array}$ & $\begin{array}{c}\text { Pillar } 3 \\
\text { Market Readiness } \\
\text { (18) }\end{array}$ & $\begin{array}{c}\text { Pillar } 4 \\
\text { Intellectual } \\
\text { Property and } \\
\text { Research \& } \\
\text { Development (15) }\end{array}$ \\
\hline $\begin{array}{l}\text { 1.1 Regulatory } \\
\text { Environment (9) }\end{array}$ & $\begin{array}{l}2.1 \text { Business } \\
\text { Competitiveness } \\
\text { (12) }\end{array}$ & $\begin{array}{l}\text { 3.1 Training and } \\
\text { education (12) }\end{array}$ & $\begin{array}{l}\text { 4.1 Proprietary } \\
\text { protection (6) }\end{array}$ \\
\hline 1.1.1 Approval Periods & 2.1.1 Trade Balance & $\begin{array}{l}\text { 3.1.1 Student } \\
\text { Incentives }\end{array}$ & $\begin{array}{l}\text { 4.1.1 Patent } \\
\text { Procedures }\end{array}$ \\
\hline $\begin{array}{l}\text { 1.1.2 Food Safety } \\
\text { Assurance }\end{array}$ & 2.1.2 CPI & $\begin{array}{l}\text { 3.1.2 Education } \\
\text { Trends }\end{array}$ & $\begin{array}{l}\text { 4.2.2 Patent } \\
\text { Protection }\end{array}$ \\
\hline $\begin{array}{r}\text { 1.1.3 Transparency \& } \\
\text { Communication }\end{array}$ & $\begin{array}{l}\text { 2.1.3 Economic } \\
\text { Indicators }\end{array}$ & $\begin{array}{l}\text { 3.1.3 Employment } \\
\text { Trends }\end{array}$ & $\begin{array}{l}\text { 4.2 Research and } \\
\text { Development (9) }\end{array}$ \\
\hline $\begin{array}{l}\text { 1.2 Environmental } \\
\text { Restrictions (6) }\end{array}$ & $\begin{array}{l}\text { 2.2 Capital Credit } \\
\text { and Credit } \\
\text { Availability (6) }\end{array}$ & 3.1.4 Job Retraining & $\begin{array}{l}\text { 4.2.1 Federal } \\
\text { Budget }\end{array}$ \\
\hline $\begin{array}{l}\text { 1.2.1 Waste } \\
\text { Management }\end{array}$ & $\begin{array}{l}\text { 2.2.1 Government } \\
\text { Grants and Loans }\end{array}$ & $\begin{array}{l}\text { 3.2 Diversity and } \\
\text { Inclusion (6) }\end{array}$ & $\begin{array}{l}\text { 4.2.2 National Data } \\
\text { Strategies }\end{array}$ \\
\hline \multirow[t]{5}{*}{ 1.2.2 EPA \& ERA } & $\begin{array}{l}\text { 2.2.2 Foreign Direct } \\
\text { Investment per } \\
\text { Capita }\end{array}$ & $\begin{array}{c}\text { 3.2.1 Incentives and } \\
\text { Equitable } \\
\text { Workplace } \\
\text { Training }\end{array}$ & 4.2.3 Privacy Laws \\
\hline & $\begin{array}{l}\text { 2.3 Distribution } \\
\text { Networks (9) }\end{array}$ & $\begin{array}{l}\text { 3.2.2 Pay Gap } \\
\text { Analysis }\end{array}$ & \\
\hline & $\begin{array}{l}\text { 2.3.1 Large-Scale } \\
\text { Competitors }\end{array}$ & & \\
\hline & 2.3.2 Private Labels & & \\
\hline & $\begin{array}{l}\text { 2.3.3 Shipping } \\
\text { Capacity }\end{array}$ & & \\
\hline
\end{tabular}

Figure 1. International Food Innovation Index Pillars and Variables.

\subsection{Data Collection Methods}

Data was collected using qualitative and quantitative methods. Qualitative data was analyzed using thematic coding, where common themes were observed to identify a baseline among the countries. This baseline was used to create an average, which would earn a country two of a possible three points. Where a country's procedures were different than the average, those procedures were further analyzed to examine how they impacted innovation. For procedures above average, a country earned three points. For procedures which fell below the average, a country was awarded one point. Quantitative data was analyzed by finding the average within the data presented, then adding or subtracting points for specific countries, based on their performance in relation to the average.

\subsection{Limitations}

The most significant limitation affecting data collection was language. Interpreting some of the foreign documents was a challenge. While there is translation software available, the use of these technologies did not allow us to fully understand the scope and scale of some of the existing policies. As a result, in some cases, data was available but could not be accessed, or it was unclear whether the data existed. The index did reward multilingualism. For example, the primary language in the US is English; however, some US Government websites were available in up to 16 different languages. Japan, as an- 
other example, is a country whose primary language is not English, yet most Japanese resources are available in English. In the case of Italy and France, EU countries, many of the government websites were not available in English. English is generally accepted as the international language of business, so when materials relating to innovation are not available in English, this may affect the success of new innovators and their entry into foreign countries.

Government policies on data sharing also posed a barrier to data access. For example, many governments do not share a public, detailed budget, reflecting a different level of comfort with and expectation of government transparency. Additionally, many governments do not share their transportation data, but this is likely for national security reasons.

A final limitation was the weighted ranking of the indicators. As the index is currently constructed, all variables are given the same maximum value of three points.

\section{Results}

\subsection{Regulatory Environment}

Table 1 summarizes the scores awarded to each country for each indicator in the section alongside a total score for the section. Analysis follows to describe the rationale for each indicator score.

Table 1. Regulatory Environment Results.

\begin{tabular}{ccccc}
\hline Country & $\begin{array}{c}\mathbf{1 . 1 . 1} \\
\text { Approval } \\
\text { Periods } \\
(/ 3)\end{array}$ & $\begin{array}{c}\mathbf{1 . 1 . 2} \\
\text { Food Safety } \\
\text { Assurance } \\
(/ 3)\end{array}$ & $\begin{array}{c}\text { Transparency and } \\
\text { Communication } \\
(/ 3)\end{array}$ & $\begin{array}{c}\text { Section 1.1 } \\
\text { Total } \\
(/ 9)\end{array}$ \\
\hline Canada & 1 & 2 & 2 & 5 \\
United States & 1 & 1 & 3 & 5 \\
Mexico & $\mathrm{N} / \mathrm{A}$ & $\mathrm{N} / \mathrm{A}$ & 1 & 1 \\
United Kingdom & 2 & 2 & 2 & 6 \\
Italy & 2 & $\mathrm{~N} / \mathrm{A}$ & 1 & 6 \\
Germany & 2 & 2 & 2 & 3 \\
France & 2 & $\mathrm{~N} / \mathrm{A}$ & 1 & 7 \\
Netherlands & 2 & 3 & 2 & 6 \\
Japan & 3 & 1 & 2 & 6 \\
Australia & 3 & 2 & 1 & \\
\hline
\end{tabular}

\subsubsection{Product Approval Period}

The average (modal) approval time was 17 months across the UK and EU countries [15-17]. As such, the UK and EU countries were all awarded two points. Japan has an approval period of a year or more $[18,19]$, whereas Australia has a tiered approval system where all approval procedures take a year or less [20]. Shorter approval periods may increase food innovation by reducing approval costs. Therefore, both Australia and Japan were awarded an additional point. Other than scientific reviews, Canada does not have adequate publicly available data from an authoritative source to determine approval periods [21-23]. Scientific reviews can take upwards of 13 months; however, this is just one aspect of product approval. The US has two approval methods: one for ingredients generally recognized as safe (GRAS) but not FDA approved, and another approval period for food additives that require FDA approval [24]. Applying for a GRAS notification can take 180 to 270 days, whereas approval from the FDA for a food additive can take up to two years or more [25]. There is no set time frame for approval periods for colour additives. Given that slower approval periods can negatively impact innovation, both Canada and the US were awarded one point. Mexico received an N/A due to a language barrier [26].

\subsubsection{Food Safety Assurance Measures}

Most countries have guiding laws for food producers at both federal and regional levels, and some form of additional measure such as random inspections, traceability logs, 
or preventative plans. Countries were awarded two points if they had either planned or random inspections in conjunction with an additional safety measure. Countries gained an additional point if inspections were unplanned and if they had additional measures in place such as food traceability logs or preventative plans. Countries received one point if their procedures were vague, or if they failed to meet the standard procedure. Canada [27-31], the UK [17], Germany [32-34], and Australia all received two points, as they had clear policies on either planned or random inspections and a secondary safety measure. The Netherlands received three points as they conduct random inspections and require businesses to keep a traceability log [35]. The US received one point, as they conduct planned inspections without a secondary control measure [24,25,36]. Japan received one point, as their inspection procedure for locally produced foods is unclear, although inspections for imported goods are stringent [18,37]. Italy [38], France [39], and Mexico [40] received an N/A due to a language barrier.

\subsubsection{Transparency and Communication}

Firstly, governing bodies were evaluated on how clearly and effectively they communicate with consumers regarding potential contaminations, outbreaks, and changes to approved ingredients. Secondly, most countries had information available on their website in two languages and websites contained a search feature. Countries which met both requirements received two points. Countries with only one available language received one point. If countries had more than two languages available and a public feedback period regarding decisions, they were awarded an additional point.

Canada, the UK, Germany, and Japan all received two points. The Netherlands received two points because, while their site is accessible in four languages, they do not have a public feedback period regarding decisions. Mexico, Italy, France, and Australia all received one point as their websites were only available in one language. The US received three points, as their site is accessible in 16 different languages, features a search bar, site map, and text size adjustment. The US also has a public feedback period.

\subsection{Environmental Restrictions}

Table 2 summarizes the scores awarded to each country for each indicator in the section alongside a total score for the section. Analysis follows to describe the rationale for each indicator score.

Table 2. Environmental Restrictions Results.

\begin{tabular}{cccc}
\hline Country & $\begin{array}{c}\text { Waste } \\
\text { Management } \\
(/ 3)\end{array}$ & $\begin{array}{c}\text { EPA/ERA } \\
(/ 3)\end{array}$ & $\begin{array}{c}\text { Section 1.2 } \\
\text { Total (/6) }\end{array}$ \\
\hline Canada & 2 & 2 & 4 \\
United States & 2 & 2 & 4 \\
Mexico & $\mathrm{N} / \mathrm{A}$ & $\mathrm{N} / \mathrm{A}$ & $\mathrm{N} / \mathrm{A}$ \\
United Kingdom & 3 & 2 & 5 \\
Italy & $\mathrm{N} / \mathrm{A}$ & $\mathrm{N} / \mathrm{A}$ & $\mathrm{N} / \mathrm{A}$ \\
Germany & 3 & 2 & 5 \\
France & 1 & 2 & 3 \\
Netherlands & 2 & 1 & 3 \\
Japan & 1 & 2 & 3 \\
Australia & 2 & 2 & 4 \\
\hline
\end{tabular}

\subsubsection{Waste Management}

Countries were assessed on waste management protocols, including the handling of hazardous waste, wastewater treatment, and policies aimed at reducing or eliminating product packaging. Most countries have implemented comprehensive waste management policies that are publicly available on government websites. Most waste management laws required businesses to properly dispose of waste through a registered waste management 
company; this is also applicable to hazardous waste. Laws and regulations varied based on the type of waste [41]. Canada [42-48], the US [49-52], the Netherlands [53-55], and Australia [56,57] all had publicly available and comprehensive waste management laws and policies available online, all scoring two points.

Countries were awarded an additional point if they had laws or regulations that were aimed at reducing or eliminating packaging or had a larger number of strict waste management protocols. The UK has regulations requiring businesses that handle a certain amount of packaging be registered and follow specific packaging guidelines [58,59]. Germany has also implemented a packaging regulation in which packaging materials are divided into regulatory categories $[53,60,61]$. Germany's aim is to create a closed substance and waste cycle, and packaging laws can be found under the 2012 Circular Economy Act [61]. Both Germany and the UK have been awarded three points due to additional measures.

France has implemented significant regulations to reduce food waste; however, no legislation appears available on government websites pertaining to waste management or packaging $[53,62]$. Japan has waste protocols, but the details of the legislation were vague without industry-specific information [63]. Therefore, both France and Japan were awarded one point, as their waste management protocols could not be confirmed to align with the standard. Italy was given an N/A due to language barriers.

\subsubsection{Environmental Risk Assessments and Environmental Protection Acts}

Most countries require businesses and industries to complete an Environmental Risk Assessment ('ERA') when developing new products per an Environmental Protection Act ('EPA') [64]. If countries require an ERA and have an EPA or similar legislation, they were awarded two points. These countries were Canada [65], the US [24,66], the UK [67,68], Germany [61,69,70], France [38], Japan [63,71-73], and Australia [54,74]. The Netherlands was awarded one point, as no information could be found pertaining to ERAs or similar procedures [75]. Italy was given an N/A due to language barriers.

\subsection{Business Competitiveness}

Table 3 summarizes the scores awarded to each country for each indicator in the section alongside a total score for the section. Analysis follows to describe the rationale for each indicator score.

Table 3. Business Competitiveness Results.

\begin{tabular}{|c|c|c|c|c|c|c|}
\hline \multirow[b]{2}{*}{ Country } & \multirow{2}{*}{$\begin{array}{c}2.1 .1 \\
\text { Trade } \\
\text { Balance Food } \\
\text { Exports-Imports }\end{array}$} & \multirow[b]{2}{*}{$\begin{array}{c}2.1 .2 \\
\text { CPI } \\
\text { Food }\end{array}$} & \multicolumn{3}{|c|}{ 2.1.3 Economic Indicators (/3) } & \multirow[b]{2}{*}{$\begin{array}{c}\text { Section } 2.1 \text { Total } \\
(/ 9)\end{array}$} \\
\hline & & & $\begin{array}{c}2.1 .3 \\
\text { Long-Term } \\
\text { Interest Rates }\end{array}$ & $\begin{array}{c}2.1 .4 \\
\text { Exchange } \\
\text { Rates }\end{array}$ & $\begin{array}{c}2.1 .5 \\
\text { Labour } \\
\text { Productivity }\end{array}$ & \\
\hline Canada & 3 & 2 & & 2 & & 7 \\
\hline United States & 1 & 2 & & 1 & & 4 \\
\hline Mexico & 3 & 1 & & 3 & & 7 \\
\hline United Kingdom & 1 & 3 & & 3 & & 7 \\
\hline Italy & 2 & 0 * & & 1 & & 3 \\
\hline Germany & 1 & 2 & & 3 & & 6 \\
\hline France & 3 & 2 & & 3 & & 8 \\
\hline Netherlands & 3 & 3 & & 3 & & 9 \\
\hline Japan & 1 & 0 * & & 3 & & 4 \\
\hline Australia & 3 & 3 & & 1 & & 7 \\
\hline
\end{tabular}

${ }^{*}$ No data available.

\subsubsection{Trade Balance: Food Items (Exports-Imports)}

It was assumed preferable to be a net exporter, and to have a larger proportion of total imports and exports attributed to food items. Where countries have higher imports and exports of food, they likely have better existing infrastructure for new innovators. Countries with a trade balance of effectively zero were awarded two points (Italy [76]). Canada [77], Mexico [78], France [79], the Netherlands [80], and Australia [81] all had 
positive net exports, and were therefore awarded three points. The US [82], the UK [83], Germany [84], and Japan [85] all had negative net exports and were awarded one point.

\subsubsection{CPI Food Prices}

Year-over-year changes in food price inflation were calculated for each country over four periods. The averages were: 1\% inflation in 2015-2016, and 2\% in 2016-2017, 20172018 and 2018-2019. Canada [86], Germany [87], France [88] and the US [89] all received two points, remaining on average in aggregate across all four periods. Both Australia [90] and the Netherlands [91] had average inflation for two periods, and lower than average inflation for two periods, receiving three points. The UK's inflation was below average, receiving three points [92]. Italy and Japan both received a zero, as no data was available. Mexico received a one with higher-than-average inflation across all three periods [93].

\subsubsection{Economic Indicators}

Three economic indicators were grouped to provide important economic context, while ensuring that they did not outweigh the food-focused variables in the model. The same methodology was followed for both interest rates and labour productivity: the median, minimum, and maximum value for each individual country's interest rates were calculated, then interest rates were averaged for each year from 2015 to 2019 across all 10 countries [94-98]. All countries' medians, minimums and maximums were averaged to account for any outlying values, which may have skewed the mean. Each country's rate was compared to the average. Higher-than-average interest rates were scored lower as this means borrowing money is more costly for innovators. A higher-than-average rate of productivity was determined to be good for innovators.

Where countries were above the average approximately half of the time for interest rates and productivity, they received a score of two (Canada). Where countries performed more than half of the time above average, they received a score of three (the UK, France, Germany, the Netherlands, and Japan). Where countries performed more than half of the time below average, they received a score of one (the US, Mexico, Italy, and Australia). Exchange rates were considered as a secondary variable due to lack of data, and did not affect scores [99].

\subsection{Capital and Credit Availability}

Table 4 summarizes the scores awarded to each country for each indicator in the section alongside a total score for the section. Analysis follows to describe the rationale for each indicator score.

Table 4. Capital and Credit Availability.

\begin{tabular}{cccc}
\hline Country & $\begin{array}{c}\mathbf{2 . 2 . 1} \\
\text { Government } \\
\text { Grants and } \\
\text { Loans } \\
(/ 3)\end{array}$ & $\begin{array}{c}\mathbf{2 . 2 . 2} \\
\text { Foreign Direct } \\
\text { Investment per } \\
\text { Capita } \\
(/ 3)\end{array}$ & $\begin{array}{c}\text { Section } 2.2 \\
\text { Total } \\
(/ 6)\end{array}$ \\
\hline Canada & 2 & 2 & 4 \\
United States & 3 & 2 & 5 \\
Mexico & $\mathrm{N} / \mathrm{A}$ & 1 & 1 \\
United Kingdom & 2 & 2 & 4 \\
Italy & 1 & 1 & 2 \\
Germany & 2 & 1 & 3 \\
France & 1 & 1 & 3 \\
Netherlands & $0 *$ & 3 & 2 \\
Japan & 1 & 1 & 4 \\
Australia & 3 & 1 &
\end{tabular}

* Limited data available. 


\subsubsection{Government Grants and Loans}

Government grants and loans were assessed on four criteria: (1) the number of programs researchers found; (2) the diversity in programs; (3) the structure of the programs; and; (4) accessibility of program application information. On average, there were three to four programs for each sector (criteria 1), usually addressing agriculture, fisheries, and agri-food sectors (criteria 2), in the form of government grants (criteria 3). Generally, there was limited information on how to apply for funding (criteria 4). Countries were compared to this average.

Canada [100-102], the UK [103-105], and Germany [106,107] performed to average and each received two points. France [108-110], Italy [111,112], and Japan [113] had vague or limited information on funding and applications, receiving one point. For European countries, the EU might be responsible for significant funding; however, that must be communicated clearly. The Netherlands lacked data on funding [114,115]. Mexico received a score of $\mathrm{N} / \mathrm{A}$ due to language barriers.

The US and Australia were each awarded three points. The US provided numerous and diverse programs, with an accessible application database [116-120]. Similarly, Australia provided remarkably diverse funding programs, and uniquely, they offered the option of government-matched funding $[121,122]$.

\subsubsection{Foreign Direct Investment per Capita}

An average FDI per capita was calculated across all countries (\$1123 USD per person) [123]. As the per capita data has a large range (\$30/person-\$6629/person) and therefore a skewed average, countries within $+/-30 \%$ of the average received two points. Countries more than $30 \%$ above the average gained a point and countries more than $30 \%$ below the average lost a point. Though government policies impact the effects of FDI, a higher FDI is broadly understood to be beneficial for innovation, increasing links between countries and helping transfer knowledge, technology and other non-monetary benefits [123].

Canada, the US, and the UK all had FDI per capita within $30 \%$ of the average, receiving two points. Mexico, France, Germany, Italy, Japan, and Australia all had FDI per capita below the $30 \%$ threshold, receiving one point each. The Netherlands was the only country with significant FDI per capita well above average (\$6629), receiving three points.

\subsection{Distribution Networks}

Table 5 summarizes the scores awarded to each country for each indicator in the section alongside a total score for the section. Analysis follows to describe the rationale for each indicator score.

Table 5. Distribution Networks Results.

\begin{tabular}{|c|c|c|c|c|}
\hline Country & $\begin{array}{c}2.3 .1 \\
\text { Large-Scale } \\
\text { Competitors } \\
\text { (/3) }\end{array}$ & $\begin{array}{c}2.3 .2 \\
\text { Private } \\
\text { Labels } \\
(/ 3)\end{array}$ & $\begin{array}{l}2.3 .3 \\
\text { Shipping } \\
\text { Capacity } \\
\text { (/3) }\end{array}$ & $\begin{array}{c}\text { Section } 2.3 \\
\text { Total } \\
(/ 9)\end{array}$ \\
\hline Canada & 1 & 1 & 1 & 3 \\
\hline United States & 3 & 2 & 2 & 7 \\
\hline Mexico & 3 & 1 * & 1 & 4 \\
\hline United Kingdom & 2 & 2 & 3 & 7 \\
\hline Italy & 3 & 3 & 1 & 7 \\
\hline Germany & 2 & 3 & 3 & 8 \\
\hline France & 1 & 2 & $0 * *$ & 3 \\
\hline Netherlands & 1 & 3 & $0 * *$ & 4 \\
\hline Japan & $\mathrm{N} / \mathrm{A}$ & $\mathrm{N} / \mathrm{A}$ & 3 & 3 \\
\hline Australia & 1 & 2 & 1 & 4 \\
\hline
\end{tabular}

* Language barriers. ${ }^{* *}$ No data available. 


\subsubsection{Large-Scale Competitors}

Large-scale competitors and the cumulative market share held by each were considered. Only those competitors with a market share above $5 \%$ were included. The cumulative market share across the number of competitors was averaged to provide an average market share per large-scale competitor. The same-store sales were also averaged across all competitors in a country. Same-store sales measures the growth in sales, year over year, across the existing number of stores; the measure eliminates the growth effects from opening new stores or closing existing stores.

The average market share held by large competitors across all ten countries was $87 \%$ of the market, with approximately $17 \%$ held by each large competitor. Where large competitors in a country held a higher cumulative market share relative to the average, this was considered to negatively impact innovation as it reduces competition and can prevent market entry. Similarly, where the large-scale competitors held larger market shares, this was also viewed negatively, as it provides additional market control and can create barriers for innovators. For cumulative market share, there was a significant range (45-94\%), which would skew the average. To account for this, where a country's cumulative market share was within $+/-10 \%$ of the average, they were considered average. For same-store sales, a higher rate relative to the average was viewed positively. The average same-store sales was $2.8 \%$.

Germany maintained their score of two: their cumulative market share was on average, their percentage held by each competitor was higher than the average, but their same-store sales rate was also higher [124-129]. The UK also maintained their score of two, but for the opposite reason: their large-scale competitors held on average lower market shares, but their same-store sales ratio was below average [130-137].

Canada [138-145], France [146-152] the Netherlands, and Australia [153-162] were each awarded one point. All four countries were mostly below average for all considerations. In the case of the Netherlands, they were also lacking data on same-store sales [163-172]. Japan was awarded N/A due to language barriers [173-176].

The US [177-183], Mexico [138,145,184-189], and Italy [147,190-196] were awarded three points each. All three countries were characterized by a lower cumulative market share held by their large-scale competitors, lower average market shares per individual large-scale competitor, and higher-than-average same-store sales. In the case of Italy and Mexico, many grocers did not report same-store sales, but instead sales growth with minimal changes in the number of stores. As such, their same-store sales are likely overestimated.

\subsubsection{Private Label}

On average, countries had 18 different private labels, the general purpose was discount or value added to existing products, and the range was on average from discount to value added. As this index is concerned with innovation, where a country's private labels were innovative rather than simply discount or value added, the country was awarded an additional point. Countries whose major focus across competitors was discount on existing products lost a point.

The US [197-200], the UK [201-204], France [205-209], and Australia [210-212] were all awarded two points. Their number of private labels was on or close to the average and the focus of private labels appeared to be value added to existing products, but also there was a range from discount to value added.

Canada had on average fewer private labels, whose purpose was mostly discount with some value added to existing products, and with a range on average of discount to value added [213-217]. As such, Canada was awarded one point. Mexico was similarly focused on discount of existing products, but there was limited data. Mexico was awarded one point [218]. Japan received an N/A due to language barrier [219,220].

Germany [221-223], the Netherlands [171,172,224], and Italy [225-227] all use private labels as a source of innovation and were awarded three points each. These countries have 
a large range of products. The purpose of products in Italy's Coop and Selex stores, for example, extends to different values, such as environmental sustainability, fair trade, and artisanal products to target unique customer segments [155].

\subsubsection{Shipping Capacity}

A ratio was created for each shipping category, comparing shipping capacity to a country's square kilometres. An average was calculated for each measure and each ratio. Where most of the country's measures fell below the average, they were awarded one point. Where a country was partially above average and partially below average, they received two points. Where a country performed generally above average, they received three points. Where no data was available, zero points were awarded. This average was used given the available data, but does not account for population density.

The US met the average and was awarded two points [228-230]. Canada [231,232], Mexico [233-235], Italy [236,237], and Australia [238,239] all had less infrastructure than the average, receiving one point each. Australia was also missing data for ports. Similarly, Italy was missing data for airports. France [240] and the Netherlands [241] were each assigned zero points, as only rail data was available.

The UK [242-244], Germany [245,246] and Japan [247-249] were each awarded three points with above-average infrastructure across all types of shipping.

\subsection{Training and Education}

Table 6 summarizes the scores awarded to each country for each indicator in the section alongside a total score for the section. Analysis follows to describe the rationale for each indicator score.

Table 6. Training and Education Results.

\begin{tabular}{|c|c|c|c|c|c|}
\hline Country & $\begin{array}{c}3.1 .1 \\
\text { Student } \\
\text { Incentives } \\
(/ 3)\end{array}$ & $\begin{array}{c}3.1 .2 \\
\text { Education } \\
\text { Trends } \\
(/ 3)\end{array}$ & $\begin{array}{c}3.1 .3 \\
\text { Employment } \\
\text { Trends } \\
(/ 3)\end{array}$ & $\begin{array}{c}3.1 .4 \\
\text { Job } \\
\text { Retraining } \\
(/ 3)\end{array}$ & $\begin{array}{c}\text { Section } 3.1 \\
\text { Total } \\
(/ 12)\end{array}$ \\
\hline Canada & 2 & 3 & 2 & 3 & 10 \\
\hline United States & 2 & 3 & 3 & 2 & 10 \\
\hline Mexico & $\mathrm{N} / \mathrm{A}$ & $\mathrm{N} / \mathrm{A}$ & $\mathrm{N} / \mathrm{A}$ & $\mathrm{N} / \mathrm{A}$ & $\mathrm{N} / \mathrm{A}$ \\
\hline $\begin{array}{l}\text { United } \\
\text { Kingdom }\end{array}$ & 1 & 2 & 1 & 3 & 7 \\
\hline Italy & 0 & 2 & $1^{* *}$ & 1 & 3 \\
\hline Germany & 3 & $1 *$ & 3 & 1 & 7 \\
\hline France & 1 & 1 * & $1 * *$ & 1 & 2 \\
\hline Netherlands & 1 & 1 * & $1 * *$ & 1 & 2 \\
\hline Japan & 1 & $1 *$ & $1^{* *}$ & 2 & 3 \\
\hline Australia & 3 & $1 *$ & $1 * *$ & 2 & 5 \\
\hline
\end{tabular}

\subsubsection{Student Incentives}

This category examined the financial or social supports to encourage post-secondary education. Values were awarded based on the number of supports countries had in place, specifically to provide support for racialized or otherwise marginalized individuals. Most countries offer federal grants and loans to all students. Countries that only offer grants and loans but have no specific incentives to attract diverse audiences were awarded one point (the UK, France, the Netherlands and Japan). Countries that offered federal grants and loans plus additional incentives to individuals from lower socio-economic backgrounds, Indigenous students, or students from visible minorities were awarded two points. These countries are Canada [250,251], the US [252,253], and Australia [254]. In Germany, postsecondary school is often state subsidized, and most students can attend post-secondary education for free [255]. Most graduate-level programs have tuition fees; however, these 
are much lower compared to other countries. Students who do need to pay for tuition can apply for a zero-interest government loan and federally funded scholarships. As Germany offers largely free post-secondary education, they have been awarded three points, as lack of financial resources is often a barrier to students [256,257]. Italy has been awarded a zero due to lack of data.

\subsubsection{Education Trends}

This category examined the level of education required for careers in the food industry and graduate employment rates. In Canada, graduates working in food production saw an 85-91\% employment rate depending on level of education, with the lowest employment level being those who had received a master's degree [252]. Due to high employment rates and the fact that the most employable individuals are those with either a college diploma or bachelor's degree, Canada earned three points. In the US, most individuals working in food sciences and production have a bachelor's degree, while food science technicians often have a high school diploma or some post-secondary education but no degree. Employment rates are high and considering that individuals can enter the industry with various levels of education and training, the US earned three points [258].

In the UK, food science graduates see a 71\% employment rate, which is significantly lower than Canada and the US, earning the UK two points [259]. In Italy, 60\% of students find work after completion of their degree while $15.6 \%$ of students were working before or during their degree bringing the total number of graduates working to $75.6 \%[260,261]$. This employment rate resembles that of the UK; therefore, Italy earned two points in this category.

Germany, France, the Netherlands, Japan, and Australia do not appear to collect data on graduate employment rates, earning one point. Mexico received an N/A due to language barriers [262-264].

\subsubsection{Employment Trends}

This category examined the expected annual income in the food industry compared to the national average yearly income across all industries (USD). A comparison of average annual incomes for OECD countries can be found on the OECD website [265].

Canada saw annual earnings ranging from $\$ 28,747$ to $\$ 53,992$ USD per year in the fields of agriculture, food production, and food science, with most employees earning an average of $\$ 39,119$ USD per year [266]. While employment rates are high, the average annual wage is $\$ 48,849$ USD per year, making the wages earned by Canadians in food production much lower than the overall average. Canada, therefore, received two points.

Individuals working in food sciences in the US earn an average wage of $\$ 65,300$ USD per year while food science technicians have an average income of $\$ 40,860$ per year [259]. The average annual income in the US is $\$ 63,093$, making the average wage for those in food production and food science higher than the national average. Furthermore, individuals have the potential to earn more money than Canadians working in food sciences or food production with lower educational requirements. The US has an $8.3 \%$ unemployment rate in the agricultural sector [267]. Because of the low unemployment rate, high earnings, and low educational requirements, the US earned three points.

The national average yearly income in the UK is $\$ 44,770$ USD, while the average income for those working in food and beverage production is $\$ 693$ per week or approximately $\$ 36,036$ USD per year assuming 52 work weeks [259]. The average income for those working in agriculture is $\$ 531$ per week or approximately $\$ 27,612$ USD per year, making the earnings of both fields of employment within the food industry below the national average of yearly earnings. Due to the lower employment rates and low income, the UK was awarded one point.

In Germany, the average yearly income is $\$ 49,813$ USD [268]. The average yearly income for individuals in technical and scientific fields is $\$ 73,881$ USD and $\$ 61,880$ USD for those in manufacturing, putting the yearly earnings of individuals in those industries 
far over the national average $[269,270]$. Overall, Germany has a $75.9 \%$ employment rate and a $3.4 \%$ unemployment rate [271]. Germany has many apprenticeship programs and, as previously stated, offers free post-secondary education; however, the education level of employees is not stated in statistics [272]. Therefore, Germany was awarded two points, as they have high employment rates and high wages, but educational requirements are not specified.

France was awarded one point, as average yearly income by sector could not be found and the ILO employment rate is 50.9\% [273-275]. Italy was also given one point, as the average yearly income is $\$ 37,752$ USD overall, although individuals in technical and scientific professions make approximately $\$ 23,699$ USD per year and those in manufacturing make $\$ 27,804$ USD per year [276]. Employment and unemployment rates for Italy are not publicly available. The Netherlands was given one point because, although they have an exceptionally low overall unemployment rate of $3 \%$, no data regarding wages was available [277-279]. Japan was also awarded one point, as the employment rate is $60 \%$ for individuals aged 15 and over, and data surrounding wages was not available [280]. Australia received one point, as employment rates are recorded in numbers of people instead of percentages, making the data unusable for these purposes, and the average yearly income is $\$ 53,349$ USD, although individuals in manufacturing make approximately $\$ 43,923$ USD per year and those in technical and scientific professions make approximately $\$ 56,140$ USD per year [281,282].

\subsubsection{Job Retraining}

Most countries offer retraining targeting at least two of the following groups: Indigenous people, youth, seniors, and veterans. Countries which offer job training to at least two of these groups received two points. Countries that offered programs to more groups of people or had broader retraining strategies received three points. Countries that only offered incentives toward one group or had no specific training programs for any group, received one point. The US [252], Australia [283], and Japan [284] all received two points. Canada received three, because it offers several training programs aimed at veterans, youth, and Indigenous people [246]. The UK received three points because of its recently implemented national retraining scheme, which provides job training to low-income individuals over the age of 24 without a degree and it also has a government graduate scheme [285]. Italy, Germany, France, and the Netherlands all received one point as their retraining programs were unclear and only information regarding apprenticeships could be found $[286,287]$.

\subsection{Diversity and Inclusion}

Table 7 summarizes the scores awarded to each country for each indicator in the section alongside a total score for the section. Analysis follows to describe the rationale for each indicator score.

Table 7. Diversity and Inclusion Results.

\begin{tabular}{cccc}
\hline Country & $\begin{array}{c}3.2 .1 \\
\text { Equitable Training } \\
\text { Programs and } \\
\text { Incentives }\end{array}$ & $\begin{array}{c}\text { 3.2.2 } \\
\text { Pay Gap }\end{array}$ & $\begin{array}{c}\text { Section } 3.2 \\
\text { Total } \\
(/ 6)\end{array}$ \\
Canada & 3 & 1 & 4 \\
United States & 3 & 2 & 5 \\
Mexico & $\mathrm{N} / \mathrm{A}$ & $0 * *$ & 0 \\
United Kingdom & 2 & 3 & 5 \\
Italy & 1 & 3 & 4 \\
Germany & 1 & 1 & 2 \\
France & 1 & $0^{*}$ & 1 \\
Netherlands & 2 & $0 * *$ & 2 \\
Japan & 3 & $0^{* *}$ & 3 \\
Australia & 2 & $0^{* *}$ & 2 \\
\hline
\end{tabular}

* France does not collect gender-based data. ${ }^{* *}$ Wage and earnings data not available. 


\subsubsection{Incentives and Equitable Training Programs}

Diversity within a workplace positively affects innovation and contributes to overall employee satisfaction and retention [288-290]. This category examined the prevalence of financial support for individuals from minority groups to pursue education, continue education or open businesses, government diversity and inclusion statements and initiatives, and equitable training programs for businesses. On average, most countries had a diversity statement or anti-discrimination legislation. Australia [291,292], the UK [293,294], and the Netherlands [280] all have diversity statements and anti-discrimination legislation clearly found on their websites, earning two points each. Canada [102], the US [252], and Japan [295] all have anti-discrimination legislation, diversity statements, and at least two federal initiatives aimed at diversifying the workforce, earning three points each. No diversity statements or legislation could be found for Germany, Italy, or France; therefore, these countries received one point. The information available in English for both France and Italy was limited.

\subsubsection{Pay Gap}

An average percentage gender pay gap was constructed from the national statistics data of each country, to which each country was compared [87,266,296-301]. The average pay discrepancy between males and females is $18.7 \%$. Countries whose pay discrepancy fell between $15 \%$ and $20 \%$ were awarded two points. Table 8 summarizes the data.

Table 8. Pay Gap Data per Country.

\begin{tabular}{ccc}
\hline Country & Pay Gap & Points Awarded \\
\hline Canada & 29.8 & 1 \\
United States & 16.9 & 2 \\
Mexico & No wage data collected & 0 \\
United Kingdom & 6.5 in agriculture to 12.1 in & 3 \\
Italy & manufacturing & 3 \\
Germany & for manufacturing & 1 \\
France & for scientific and technical fields; 13.9 & 0 \\
Netherlands & No gender-based data collected & 0 \\
Japan & No data available & 0 \\
Australia & No data available & 1
\end{tabular}

\subsection{Proprietary Protection}

Table 9 summarizes the scores awarded to each country for each indicator in the section alongside a total score for the section. Analysis follows to describe the rationale for each indicator score.

Table 9. Proprietary Protection Results.

\begin{tabular}{cccc}
\hline Country & $\begin{array}{c}\mathbf{4 . 1 . 1} \\
\text { Patent } \\
\text { Procedures }\end{array}$ & $\begin{array}{c}4.1 .2 \\
\text { Patent } \\
\text { Protection }\end{array}$ & $\begin{array}{c}\text { Section } \\
\text { Total } \\
\text { (/6) }\end{array}$ \\
\hline Canada & 2 & 1 & 3 \\
United States & 3 & 2 & 5 \\
Mexico & 2 & 2 & 4 \\
United Kingdom & 2 & 3 & 5 \\
Italy & 2 & 2 & 4 \\
Germany & 2 & 2 & 4 \\
France & 1 & 1 & 2 \\
Netherlands & 2 & 1 & 3 \\
Japan & 1 & 3 & 4 \\
Australia & 1 & 2 & 4 \\
\hline
\end{tabular}




\subsubsection{Patent Procedures}

On average, across the ten countries, patent applications take 36 months, there is no differentiation in fees, and the patent lasts 20 years.

The US performed above average, with clear procedures and timelines, receiving three points [302-305]. Canada, Mexico [306-310], the UK, France, Germany, the Netherlands, and Italy all received two points. Canada creates a lower fee schedule for smaller entities, but otherwise performed to the average [311-315]. The UK [316,317], Germany [318-320], the Netherlands [321-323], and Italy [324,325] all performed to the average on all criteria.

Japan, Australia, and France each received one point. While Japan performed to the average for almost all criteria, they have additional translation fees for patent applications in a foreign language [326-330]. This requirement creates a barrier to patent applications and places a cost on innovators, so Japan received one point. Australia performed to the average for fee schedules and patent lifetime with no additional barriers, but the application length was unclear from government websites [331-333]. France received one point. France created lower fees for non-profit organizations focused on research or teaching, but they also required patent applications be submitted in French $[334,335]$. The length of the French patent process was also unclear.

\subsubsection{Patent Protection, Enforcement and Monitoring}

All ten countries have federal legislation to protect patents; however, countries differed in how they addressed patent breaches. In most countries, regular courts, as opposed to specialized patent courts, hear patent breach actions. Penalties in most countries include injunctions, damages, or various orders. The average limitation period is five years in most countries.

The UK [336-338] and Japan [339-342] earned three points for above-average procedures to protect patents. The US, Mexico, Germany, Italy, and Australia were all awarded two points. The US performed to average, except for a limitation period one year above average on legal actions [343]. Mexico has specialized courts, but they have a noticeably short limitation period of two years on legal action, so their points remained unchanged [344]. Italy performed to average [345-347], as did Australia [348,349]. Germany, on the other hand, has specialized patent courts, and administrative boards to hear patent breach cases, which can reduce costs [350,351]. The country, however, includes imprisonment as a punishment when a patent has been breached. Imprisonment appears disproportionate to the crime of patent infringement across countries in this study.

Canada [352,353], the Netherlands [354,355], and France [335] each received one point. All three countries performed to average, except for their penalties: all three countries include imprisonment for breach of patent.

\subsection{Research and Development}

Table 10 summarizes the scores awarded to each country for each indicator in the section alongside a total score for the section. Analysis follows to describe the rationale for each indicator score. 
Table 10. Research and Development Results.

\begin{tabular}{|c|c|c|c|c|}
\hline Country & $\begin{array}{c}\text { 4.2.1 } \\
\text { Federal } \\
\text { Budgets }\end{array}$ & $\begin{array}{c}4.2 .2 \\
\text { National Data } \\
\text { Strategies }\end{array}$ & $\begin{array}{c}4.2 .3 \\
\text { Data Privacy } \\
\text { And Access }\end{array}$ & $\begin{array}{c}\text { Section } 4.2 \\
\text { Total } \\
(/ 9)\end{array}$ \\
\hline Canada & 2 & 3 & 2 & 7 \\
\hline United States & 3 & 3 & $0 * *$ & 6 \\
\hline Mexico & $\mathrm{N} / \mathrm{A} *$ & 1 & 1 & 2 \\
\hline United Kingdom & 3 & 1 & 3 & 7 \\
\hline Italy & $\mathrm{N} / \mathrm{A} *$ & 0 * & 2 & 2 \\
\hline Germany & $\mathrm{N} / \mathrm{A} *$ & 0 & 2 & 2 \\
\hline France & $\mathrm{N} / \mathrm{A} *$ & 1 & 2 & 3 \\
\hline Netherlands & 2 & 3 & 2 & 7 \\
\hline Japan & 1 & 1 & 2 & 4 \\
\hline Australia & 3 & 3 & 1 & 7 \\
\hline
\end{tabular}

\subsubsection{Federal Budget}

This section included the funding programs available for food innovation. Data was largely inaccessible, so an average could not be defined. The total expenditure in each country's budget for food research and innovation was recorded, then used to calculate that value as a percentage of total budget expenditure; however, complete data from government budgets could be found only for Canada, the US, the UK, the Netherlands, and Australia. Otherwise, budgets were unavailable (Mexico, France, Germany, Italy) or vague (Japan [356]). If it was possible for an innovator to find new funding for food innovation initiatives, countries received two points. An additional point was awarded if it would be possible for an innovator to determine specific initiatives being awarded funding. If it was unclear that there was food-specific funding, the country received one point.

Canada and the Netherlands each received two points. Canada had limited new food innovation and research funding programs, and it was moderately difficult to find the information $[357,358]$. The Netherlands had broad categories of funding, but it was difficult to navigate their budgetary information [359]. In both cases, an innovator could be aware that there was food research funding available.

Japan received one point, as there was some information available, but it was unclear and unspecific. France, Mexico, Germany, and Italy each received N/A, as it was unclear whether data existed due to language barriers.

Finally, the US [360,361], the UK [362], and Australia [363,364] were each awarded three points as funding programs were clearly defined and the information was accessible.

\subsubsection{National Data Strategy}

To examine national data strategies, the following criteria were considered: whether a complete data strategy existed; which years it covered; whether it applied to both private and public sectors; whether it contained concrete steps and/or a budget; and the strategy's accessibility. Across all ten countries, for those with data, there was some sort of data strategy-complete or not. On average, strategies were from 2016 or more recent, lacked concrete steps and lacked budgets; however, they were otherwise accessible. On average, strategies only applied to the public sector (covering only one sector).

Mexico, the UK, France, and Japan all received one point. While Mexico's strategy applied to both sectors, it was incomplete, from 2013, had no concrete steps, no budget, and was difficult to find [365]. The UK's data strategy was also incomplete, as it is currently being developed. The UK's strategy will apply to both sectors, and information about it was easily found, but at this time there are no concrete steps or budgets [366]. France's strategy was difficult to find with no concrete steps or budget [367-370]. Finally, Japan's strategy was difficult to find, unclear which sector it applies to, and is from 2012 to 2013 [371,372]. It is possible that the country is now using legislation instead of policy, but this remains 
unclear. Data was not available for either Germany [373] or Italy, so each country received zero points.

Canada, the US, the Netherlands, and Australia were each awarded three points. While precise actions were not evident in Canada's strategy and there is no budget, it was easy to find, complete and recent, and applies to both sectors [374,375]. The US was one of the unique budgets to have both clear actionable steps and a budget, but it only applies to government [376]. The Netherlands produced two separate strategies for the public and private sector in 2019 with budgets and clear actionable items that are easy to find $[377,378]$. Australia has no budget, but the strategy was easy to locate, applies to both sectors with concrete steps, and covers 2015-2020 [56,379,380].

\subsubsection{Data Privacy and Restrictions}

Data privacy and use laws were assessed by examining which level of government implements the scheme, who is responsible for oversight, the scope of both laws (public and/or private sector), and the penalties for breaches. Most countries have a federal act, with government actors performing oversight activities, applying to both sectors, and with penal fines.

Canada was awarded two points. Canada has separate laws for the public and private sectors, acknowledging the different contexts [381-384]. The penalties for government breaches of privacy laws, however, appear to be only recommendations following investigations by another government entity [385].

The EU countries (the UK, France, Germany, the Netherlands, and Italy) are subject to the same EU regulation and oversight body. As such, this reduces costs for innovators who must only understand one data privacy and handling law for all EU countries. The penalties under the regulation differ for each country. The UK was awarded three points as they benefitted from the supranational scheme, and otherwise performed to average, with fines in the case of a breach [386-388]. France was awarded two points, as penalties can include "any security measure necessary," which appears to be a vague and broad discretionary penalty $[389,390]$. Germany was awarded two points because, while they benefit from the singular EU law, their penalty for breach of the law can be imprisonment, which is much harsher than the average penalty (fines) indicating it might be too severe [152]. Finally, both the Netherlands [391] and Italy [346] were awarded two points because there was no information available on penalties. Clear expectations and clear consequences are considered important.

Japan was awarded two points as they performed to average, but penalties were far more severe than the average penalty of fines [392,393]. Penalties for a breach can include imprisonment or work terms.

The US was given zero points as states handle data privacy laws, so there was no federal data available. Regional-level laws can create costs for innovators expanding across states.

Mexico and Australia were awarded one point. Mexico has one law, applying only to the private sector with no accessible information regarding penalties [394]. In Australia, there is a combination of federal and state legislation. Federal legislation is limited in scope and applies only to the public sector and any organization making over $\$ 3$ million AUD annually [395-397].

\section{Discussion}

\subsection{Determining Final Rankings}

Based on the scores for each pillar, the results were determined from both an unadjusted final weighting but also from a re-weighted ranking not to penalize countries for which data was not available/accessible. Weighted results re-balance the data to more accurately reflect how countries are performing based on metrics for which data was available. To re-weight the results for countries where data was unavailable, a score was created only using the pillars for which a score could be found. For example, if a country did not 
have data for an indicator, that indicator was removed from their final score calculation. It has thus been concluded, using the re-weighted ranking, that the UK ranked first, the US second, Germany third, Australia fourth, Canada fifth, the Netherlands sixth, Japan seventh, Mexico eighth, France ninth, and Italy tenth (see Table 11).

Table 11. Overall Rankings.

\begin{tabular}{|c|c|c|c|c|c|c|c|c|c|c|c|}
\hline Country & $\begin{array}{c}\text { Sec } 1 \\
\text { Total } \\
/ 15\end{array}$ & $\begin{array}{c}\text { Rank } \\
\text { Pillar } \\
\quad 1\end{array}$ & $\begin{array}{c}\text { Sec } 2 \\
\text { Total } \\
/ 24\end{array}$ & $\begin{array}{c}\text { Rank } \\
\text { Pillar } 2\end{array}$ & $\begin{array}{c}\text { Sec } 3 \\
\text { Total } \\
/ 21\end{array}$ & $\begin{array}{c}\text { Rank } \\
\text { Pillar } 3\end{array}$ & $\begin{array}{c}\text { Sec } 4 \\
\text { Total } \\
/ 15\end{array}$ & $\begin{array}{c}\text { Rank } \\
\text { Pillar } \\
4\end{array}$ & $\begin{array}{c}\text { Total } \\
\text { Score } \\
/ 75\end{array}$ & Rank & $\begin{array}{c}\text { Final } \\
\text { Rank } \\
\text { (Weighted } \\
\text { Results) }\end{array}$ \\
\hline Canada & 9 & 5 & 14 & 6 & 14 & 2 & 10 & 4 & 47 & 3 & 5 \\
\hline United States & 9 & 5 & 16 & 3 & 15 & 1 & 11 & 2 & 51 & 2 & 2 \\
\hline Mexico & 1 & 10 & 12 & 8 & 0 & 10 & 6 & 7 & 19 & 10 & 8 \\
\hline $\begin{array}{l}\text { United } \\
\text { Kingdom }\end{array}$ & 11 & 1 & 18 & 1 & 12 & 3 & 12 & 1 & 53 & 1 & 1 \\
\hline Italy & 3 & 9 & 13 & 7 & 7 & 6 & 5 & 10 & 28 & 9 & 10 \\
\hline Germany & 11 & 1 & 17 & 2 & 9 & 4 & 6 & 7 & 43 & 5 & 3 \\
\hline France & 6 & 8 & 16 & 3 & 3 & 9 & 10 & 4 & 35 & 6 & 9 \\
\hline Netherlands & 10 & 3 & 12 & 8 & 4 & 8 & 6 & 7 & 32 & 7 & 6 \\
\hline Japan & 9 & 5 & 9 & 10 & 6 & 7 & 8 & 6 & 32 & 7 & 7 \\
\hline Australia & 10 & 3 & 15 & 5 & 8 & 5 & 11 & 2 & 44 & 4 & 4 \\
\hline
\end{tabular}

\subsection{Applying the Index: Canada as an Example}

While a final ranking is helpful for an aggregate picture of food innovation environments, it is also helpful to examine each country to see where their strengths lie and where they could make improvements, perhaps using other countries' actions as a template. For example, Canada had a final rank of third and a weighted rank of fifth. Examining the pillars, it appears that Canada performed relatively well in most pillars, but that it saw lower scores in Pillar 1 (Regulatory Environment) and Pillar 2 (Business Competitiveness) relative to its scores in Pillar 3 (Market Readiness) and Pillar 4 (Intellectual Property and Research and Development). In Pillar 1, Canada performed to the average in terms of Food Safety Assurance (1.1.2) and Transparency and Communication (1.1.3), but received a lower score in Product Approval Periods (1.1.1) because public websites lacked clear information around product approval processes and timelines. A review of the rankings in 1.1.1 also shows that Australia and Japan performed well when it comes to product approvals relative to Canada, so these two countries can be examined and used as models for any improvements to the Canadian system. The rankings in this article not only identify specific issues for each country, but also provide information as to which countries are excelling in which policy areas. This information is important as it promotes efficiency in new policy making while also reducing the costs of policy making. In the future, it will be interesting to revisit the index and assess how countries are doing, in relation to others. Given the risks and challenges countries are facing due to climate change, and an increasingly intertwined global economy, it will become critical to review how countries are performing by assessing specific metrics over several years. The idea is not necessarily to generate competition amongst countries included in the survey, but rather to get countries to learn more from one another.

\section{Conclusions}

The aim of this paper was to identify and compare food innovation policies using benchmarking across ten countries. This paper provides a final ranking, but the sole aim of this paper was not to determine which country performed the best. Rather, what this paper more importantly contributes to the literature is important comparisons which can be used by countries when considering how to improve their own policies in specific areas such as government grants, for example, or research and development policies. As noted in the Methodology section, the ultimate results were limited due to government transparency and also language barriers. These challenges were particularly prevalent in 
the data collected for Mexico. The re-weighted ranking provided in the discussion section aims to account for lack of data available (see Table 11).

In essence, the creation of this index points to areas in which countries can improve their performance in food innovation, based on chosen indicators. Most notably, as global food systems mature over time, benchmarking reports will increasingly reward consistency in high performance and transparency. To improve and support future food innovation benchmarking efforts, funding harmonized food innovation data collection is recommended, as is hosting a food innovation summit for nations to find consensus on common robust food innovation performance measurements, drawing on metrics from this study, among others.

While this model provides an important starting point and exercise in benchmarking innovation across many different countries, future research might consider expanding the model to include more variables. For example, a future model might consider including more data related to the effects of climate change or health crises on food producers and innovation. A future iteration of the model might also include more countries or take a regional perspective to the countries already listed. Finally, a future model might also consider weighting the indicators differently instead of all of them being weighted the same so as to emphasize the lesser or greater impacts of certain variables. The opportunities to expand this model are endless, but what is most important is that any expansion will continue to acknowledge that no country nor food producer operates in a vacuum. Should this model be expanded and new data collected, the conclusions section should also serve to provide a comparison between these results and those collected in the future. Global food innovation environments are interconnected and will only continue to be further integrated in the future.

Author Contributions: Conceptualization, S.C.; methodology, S.C., A.H., L.H.; validation, J.V., M.J.; formal analysis, M.J.; investigation, A.H., L.H.; resources, J.V.; data curation, A.H., L.H., J.M.; writing—original draft preparation, A.H., L.H., J.M.; writing—review and editing, S.C., A.H., L.H., M.J.; visualization, A.H., L.H.; supervision, S.C.; project administration, J.V.; funding acquisition, J.V. All authors have read and agreed to the published version of the manuscript.

Funding: This research was funded by Innovation, Science and Economic Development Canada (MLSB).

Institutional Review Board Statement: Ethical review and approval were waived for this study, due to exclusive use of secondary data.

Data Availability Statement: Not applicable.

Conflicts of Interest: The authors declare no conflict of interest.

\section{Appendix A. Indicator Descriptions}

Appendix A.1. Regulatory Environment

Appendix A.1.1. Approval Periods for New and Novel Food Products

New and novel food products must undergo federal approval before being made available on the consumer market, to protect consumers from potentially harmful substances and ingredients. The length of time it takes for a novel food product to receive approval can impact innovation. Product approval times are largely publicly available through government websites. Each approval period was recorded, and an average was created. Longer approval periods may impede innovation, as they create barriers to manufacturers interested in releasing new products.

\section{Appendix A.1.2. Food Safety Assurance Measures}

Food safety assurance measures include an analysis of each country's reporting structure for breaches of food safety; potential repercussions; and protocols enforced to ensure the quality of food being produced and distributed. Countries may implement additional protocols, such as audits or inspections as required. Information regarding food safety 
protocols is widely available through government websites, the websites of health and safety monitoring divisions, and reports from federal health and safety organizations. Food safety and monitoring is an important aspect of innovation, as consumers want assurance that the products they consume are safe and free from harmful additives or contaminants. Implementing proper food safety assurance measures could increase the quality of products produced, as well as the level of trust consumers have in food manufacturing businesses, impacting innovation through consumers trusting new products, as they can be assured the product has been tested and inspected for harmful materials.

\section{Appendix A.1.3. Transparency and Communication}

Each country was evaluated on the transparency of information, which includes the quantity, quality, and currency of publicly available information surrounding food processing laws, health and safety laws, and other industry information relevant to both consumers and producers. Transparency was evaluated on accessibility features of government websites, including available languages and features such as text-to-speech or text adjustment. Communication was evaluated based on the various communication methods governments use to disseminate crucial information regarding food safety or production, or methods in which governing bodies incorporate civilian and industry feedback into decisions regarding legislation affecting food production. All information for this section was found through systematically evaluating government websites and noting the accessibility features available on the home page, viewing site maps, and looking for contact forms or public engagement forums.

\section{Appendix A.2. Environmental Restrictions}

Appendix A.2.1. Waste Management and Packaging Laws

This section examined the prevalence of laws regarding waste management and packaging, including legal responsibility of manufacturers to manage waste created by products throughout production or after consumption by the consumer. Packaging and waste laws may affect the creation of certain packaged and processed products, and restrictive packaging and waste laws may force producers to create new solutions to find more environmentally sustainable packaging solutions. This may affect innovation, as countries require materials that encounter food products to undergo environmental risk and health assessments, similar to the procedure of approving novel food products. At the same time, many consumers are becoming increasingly conscious of their environmental footprint and are interested in consuming environmentally responsible products. Laws that encourage companies to produce products in a more environmentally conscious manner may in turn increase the products appeal to more consumers [64,237].

\section{Appendix A.2.2. Environmental Risk Assessments}

Environmental risk assessments (ERAs) are procedures put in place by government divisions to ensure that the manufacturing, production, or distribution of new and novel food products do not have irreversible negative effects on the physical environment, including plant, animal, and human health. ERAs are often dependent on the type of product being proposed, and the requirements for environmental risk assessments vary based on country and product. While stringent ERAs may have longer observation or application procedures, less stringent ERAs may lead to companies releasing or creating products that are unsuitably harmful to the natural environment, or human, plant, or animal health. Information on ERAs is publicly available through federal environmental departments and government websites. ERAs were included as a metric, due to the fact that ERAs help mitigate health risks as well as environmental damage, and having clear policies ensures that companies are following laws and upholding their social responsibility to protect the environment and consumers to the best of their ability. 


\section{Appendix B. Business Competitiveness}

\section{Appendix B.1. Economic Indicators}

Appendix B.1.1. Exportation and Importation of Food Products

Statistics observing the quantity of food products being imported and exported are publicly available through a database hosted by MIT. Trade activity is tracked in a dollar amount, and the following trade areas were recorded: foodstuffs, vegetables, animal products, and by-products. By quantifying the amount of food and food products countries import and export, it is better understood how the food and beverage industry contributes to a country's trade level (percentage of GDP exported) and trade balance (the difference between exports and imports).

\section{Appendix B.1.2. Consumer Price Index}

The consumer price index (CPI) measures the price of a specific basket of goods and, when compared to a base year, provides a measure of inflation. CPI is often recorded specifically for food products to provide a measure of food price inflation in a country. CPI is generally measured by government statistics departments and provided on their websites as annual measures. If it is not available there, a country's central bank may provide the measurement. The CPI contributes to an overall picture of the food market from the consumer's point of view. The CPI might also be worth considering in comparison to other countries, to determine where an innovator can receive a relatively higher price for their products, or to consider where price changes are more volatile and might not lead to a consistent income for their business.

\section{Appendix B.1.3. Annual Long-Term Interest Rate}

The long-term interest rate measures the rates of government bonds traded on the market and provides an indication of the overall interest rates affecting business investments as markets are often integrated; the OECD measures the annual long-term interest rates for each country. While government funding may be available to innovators, the cost of bank loans is important for innovation and can be indicated by interest rates. Where a country experiences higher interest rates, borrowing money is more costly for innovators and can be a barrier to innovation or place more pressure on governments to provide funding.

\section{Appendix B.1.4. Annual Exchange Rates}

Most countries operate on a floating exchange rate, meaning the exchange rate changes in response to other countries' exchange rates. Exchange rates indicate the relationship between the price of domestic goods and the price of foreign goods. Exchange rates in terms of Canadian dollars are published by the Bank of Canada. An increase in the value of a country's currency relative to the Canadian dollar means the country's goods are relatively more expensive. This balance impacts a country's ability to import and export goods, including food.

\section{Appendix B.1.5. Labour Productivity}

Labour productivity measures the growth in GDP per hour worked. Data about the food sector's labour productivity can be collected from the OECD. This variable contributed to an overall picture of each economy's productivity and allowed for the assessment of innovation in countries with higher labour productivity relative to other countries.

\section{Appendix B.2. Capital Credit and Credit Availability}

Appendix B.2.1. Government Grants and Loans

This section evaluated the prevalence of monetary support provided by federal bodies to businesses within the agri-food and food and beverage industries to incentivize innovation within established industries. This metric was measured by the availability of funding 
programs, how funding is dispersed, and the accessibility of information regarding federal funding. Information on funding was found through consulting government websites and through affiliated databases. Government loans are often provided at lower interest rates, reducing the cost of borrowing money for innovators. Furthermore, when government grants are available, innovators can take on less debt from the private sector and reallocate those funds into their innovations.

\section{Appendix B.2.2. Foreign Investment}

Foreign direct investment considers the inflow of foreign capital into another country. Annual foreign direct investment inflow data is available from the OECD. Foreign investments not only provide additional capital to companies, but along with the capital, there might also be increased economic growth and new technologies brought to the market because of foreign involvement. Population data was retrieved to create a measure of foreign direct investment per capita to compare across countries and account for different sizes in populations and economies. When it comes to innovation, new flows of capital and technology will be important for countries as they continue to grow.

\section{Appendix B.3. Distribution Networks}

\section{Appendix B.3.1. Number of Large-Scale Competitors}

The number of large-scale competitors was assessed based on the percentage of food market share in a country relative to other competitors and same-store sales. The number of large competitors indicates market structures that innovators face when introducing new products. Information about companies is available through company websites, statistics groups, and through governing bodies. Countries which have fewer large-scale competitors might see these companies having greater market influence. New innovations likely need to adhere to the standards and policies dictated by the large-scale corporations to be introduced through their networks.

\section{Appendix B.3.2. Prevalence of Private Labels}

This category assessed whether private labels exist in a country's grocery industry, and how successful the private labels are based on volume of private label products and the focus of these products. Data was available on companies' websites. Private label success will affect where innovation occurs. For example, if a private label is successful, it will be a barrier to market entry for a new product outside of the label. Innovation may, in that case, occur through the label rather than by new market entry.

\section{Appendix B.3.3. Shipping Capacity}

This category examined a country's access to ports, airports, and trains. Shipping capacity is important for products to get to market, both domestically and internationally. The number of ports, airports, or railways present in a country all affect a country's shipping capacities. Transportation information was found on the transportation agencies' websites, government websites, or third-party websites. Large-scale competitors already have distribution networks in place, but smaller innovators entering the market need access to transportation and shipping to distribute their products.

\section{Appendix C. Market Readiness}

\section{Appendix C.1. Training and Education}

Appendix C.1.1. Incentives for New Students

The availability of federal grants to prospective students may affect their decisions to pursue post-secondary education, whether through university, college, trade school, or apprenticeships. As the cost of post-secondary education rises, young people are often forced to take out large loans to pay for education, although federal grants and scholarships can also be awarded to students seeking to further their education. Information on the avail- 
ability of grants and scholarships was found through government websites and through education departments. Countries with lower tuition rates and more funding options may incentivize citizens to pursue higher education, as it creates less financial burden. Skilled labourers, technicians, technologists, and other skilled workers are needed in the agri-food and food and beverage industries. A lack of students pursuing higher education or training that could be applicable to these fields could result in future underemployment, lower productivity, and lower innovation.

\section{Appendix C.1.2. Education Trends}

This section examined graduate employment rates as well as the degree of education required to gain employment within the agri-food and food and beverage industries. Graduate employment rates can be found through analyzing employment statistics found on government websites through the education department or government open-data repositories. High employment rates indicate a need for professionals within a sector and may also incentivize prospective students to pursue careers in specific industries if they feel as though they are highly likely to gain employment after graduation. Graduate employment rates are often distinguished by level of education. If it is a trend within an industry to hire individuals with a high level of education, this could create a barrier to individuals looking to enter an industry, as pursuing higher education is costly and can be a lengthy process.

\section{Appendix C.1.3. Employment Trends}

This category examined the employment rate within agriculture and food manufacturing industries, and annual wages in comparison to the national average wage of each country. Average annual wages are available from the OECD; individual countries should collect employment data by sector as well as wage data by sector. Countries with high employment rates or above average earnings could incentivize individuals to work in food manufacturing or agri-food industries, as they would likely gain employment and earn better wages. If employment and wages within these sectors are low, individuals may be discouraged from pursuing a career in these industries, as they would be less likely to gain employment or a good wage, thus potentially impacting innovation through fewer workers or inferior working conditions.

\section{Appendix C.1.4. Job Retraining Programs}

This category evaluated the prevalence of programs aimed at training individuals looking to switch careers or gain additional training to assist them in furthering their careers. Most job retraining programs are targeted toward veterans or individuals from marginalized communities who face barriers to accessing education, although the availability of federal incentives for job retraining varies based on country. Retraining incentives help individuals either advance in their current careers or change career paths, which affects innovation through potentially allowing more individuals to advance within their careers.

\section{Appendix C.2. Diversity and Inclusion}

\section{Appendix C.2.1. Incentives and Equitable Training Programs}

This section examined benefits for individuals who identify as a minority (people who identify as Indigenous, POC, disabled, LGBTQIA+, or female) and for businesses that actively participate in creating diverse workforces through training, hiring, and earning certificates. Incentives such as grants or specialized jobs were examined; incentives, diversity statements, and equitable employment opportunities were often found through government websites or the department of labour. Included in this metric were incentives for businesses, which examined the prevalence of federal diversity training initiatives, anti-discrimination laws, and diversity statements. Having a clear, transparent, and easily 
accessible anti-discrimination law ensures that minorities can be protected within the workplace and can gain easy access to a document that outlines their rights. Federal diversity training initiatives often reward businesses that complete the training with certain certifications. Businesses that participate in the training may also have employee groups that act on the behalf of minorities to advocate for equal treatment or other types of support.

\section{Appendix C.2.2. Pay Gap Analysis}

This category examined the wage discrepancy between male and female workers within an industry. Where industry-specific wage data was not available, overall earnings were used instead. Pay discrepancies were calculated as a percentage, then averaged to create an overall average gap. Countries with high wage gaps within the agri-food and food and beverage industries may discourage women from participating in the industry as they are less likely to earn high wages. Wage data is not available by race for any country other than the United States, so gender was the only factor included when calculating the gap.

\section{Appendix D. Intellectual Property and Research and Development}

\section{Appendix D.1. Proprietary Protection}

\section{Appendix D.1.1. Patent Procedures}

Patents protect new inventions, including the following: products, compositions, machines, processes, and any improvements in these categories (Canadian Intellectual Property Office, 2018). Patents create incentives for research and development because they assure innovators that, for a limited time, they will have exclusivity over a product in the market. Patent procedures were measured by the length of time it takes for patents to be granted by the governing body, whether there are fees associated with the procedure, whether fee schedules provided allowances for different patent applications, the lifetime of the patent, and any other barriers. Information surrounding the patent procedure can be found on government websites. Patent grants that take a significant amount of time create barriers to innovation in a country because applicants may be hesitant to release a product into the market without patent protection.

\section{Appendix D.1.2. Patent Protection, Enforcement, and Monitoring}

Patents are protected by various schemes, including both domestic and international governing bodies and laws. This section examined the schemes that are available to patent holders; how patents are monitored and enforced; and the recourse available if a patent is breached or the penalties that apply. In this variable, both domestic and international schemes, available on government websites were considered. A patent will not spur innovation if it cannot be protected.

\section{Appendix D.2. Research and Development}

\section{Appendix D.2.1. Federal Budgets for Research Spending}

While the banks provide some funding, governments are an important contributor of research funding. This section focuses on government spending on research at a federal level. Research funding data was collected in two ways: (1) as total budgeted expenditure for the fiscal year 2019; and (2) as a percentage of total government spending to allow researchers to compare a unitless measure of spending across countries. This variable focused on spending in food research.

\section{Appendix D.2.2. National Data Strategies}

Countries were studied to determine whether the federal government had implemented a data policy or strategy which would be used across different sectors within the country. Data strategies were assessed considering the following: the scope of the strategy (is it for government or does it extend to the private sector); when the strategy was 
published; whether the strategy is complete; the action steps that are in the strategy and whether there is an accompanying budget for it; any unique factors to the strategy; and, finally, which government department, if available, is responsible for the strategy. Data strategies were also evaluated on presentation and accessibility (length, language, use of graphics). While privacy laws are important for dictating how data might be collected, used, and disclosed, data strategies are also important to ensure that there is data to handle.

\section{Appendix D.2.3. Data Privacy and Restrictions on Access}

Data is important to innovators. Data privacy laws affect what data can be collected and how, and what that data may be used for, or how it may be shared. Data privacy laws for each country were evaluated in terms of prevalence, scope, stringency, and penalties for breaches. Data privacy laws are available on government websites. Data privacy laws should support innovation by allowing innovators access to data on their consumers while balancing citizens' rights to privacy.

\section{References}

1. Gagliardi, D.; Niglia, F.; Battistella, C. Evaluation and Design of Innovation Policies in the Agro-Food Sector: An Application of Multilevel Self-Regulating Agents. Technol. Forecast. Soc. Chang. 2014, 85, 40-57.

2. DeMaria, F.; Zezza, A. Drivers and Barriers of Process Innovation in the EU Manufacturing Food Processing Industry: Exploring the Role of Energy Policies. Bio-Based Appl. Econ. 2020, 9, 25-52.

3. Esbjerg, L.; Burt, S.; Pearse, H.; Glanz-Chanos, V. Retailers and Technology-driven Innovation in the Food Retail Sector. Br. Food J. 2016, 188, 1370-1383.

4. Knickel, M.; Neuberger, S.; Klerkx, L.; Knickel, K.; Brunori, G.; Saatkamp, H. Strengthening the Role of Academic Institutions and Innovation Brokers in Agri-Food Innovation: Towards Hybridisation in Cross-Broder Cooperation. Sustainability 2021, 13, 4899.

5. Grimsby, S.; Kure, C.F. How Open is Food Innovation: The Crispbread Case. Br. Food J. 2018, 121, 950-963.

6. Kowalska, H.; Czajkowska, K.; Cichowska, J.; Lenart, A. What's New in Biopotential of Fuirt and Vegetable By-Products Applied in the Food Processing Industry. Trends Food Sci. Technol. 2017, 67, 150-159.

7. Gouranga, G.D. Food-feed-biofuel Trilemma: Biotechnological Innovation Policy for Sustainable Development. J. Policy Model. 2017, 39, 410-442.

8. Albertson, L.; Wiedmann, K.-P.; Schmidt, S. The Impact of Innovation-Related Perception on Consumer Acceptance of Food Innovations-Development of an Integrated Framework of the Consumer Acceptance Process. Food Qual. Prefer. 2020, 84, 103958.

9. Gemen, R.; Breda, J.; Coutinho, D.; Fernández Celemín, L.; Khan, S.; Kugelberg, S.; Newton, R.; Rowe, G.; Strähle, M.; Timotijevic, L.; et al. Stakeholder Engagement in Food and Health Innovation Research Programming-Key Learnings and Policy Recommendations from the INPROFOOD Project. Nutr. Bull. 2015, 40, 54-65.

10. Luo, J.; Guo, H.; Jia, F. Technological Innovation in Agricultural Co-operatives in China: Implications for Agro-Food Innovation Policies. Food Policy 2017, 73, 19-33.

11. Le Vallé, J.-C.; Charlebois, S. Benchmarking Global Food Safety Performances: The Era of Risk Intelligence. J. Food Prot. 2015, 78, 1896-1913.

12. Charlebois, S.; MacKay, G. World Ranking: 2010 Food Safety Performance. Johnson-Shoyama Graduate School of Public Policy, Regina, Saskatchewan. 2010. Available online: http://www.schoolofpublicpolicy.sk.ca/_documents/_publications_reports/fo od_safety_final.pdf (accessed on 1 August 2021).

13. Charlebois, S.; Yost, C. Food safety performance world ranking: How Canada is doing. In Research Network on Food Systems; University of Regina: Regina, SK, Canada, 2008.

14. Vanderlee, L.; Goorang, S.; Karbasy, K.; Vandevijvere, S.; L'Abbé, M.R. Policies to Create Healthier Food Environments in Canada: Experts' Evaluation and Prioritized Actions Using the Healthy Food Environment Policy Index (Food-EPI). Environ. Res. Public Health 2019, 16, 4473.

15. European Comission. Legislation. Available online: https://ec.europa.eu/food/safety/novel_food/legislation_en (accessed on 1 August 2021).

16. Official Journal of the European Union. Regulation (EU) on Novel Foods (2015/2283). 2015. Available online: https:/ /eur-lex.eu ropa.eu/legal-content/EN/TXT/HTML/?uri=CELEX:32015R2283\&from=EN (accessed on 1 August 2021).

17. United Kingdom. Novel Foods. Food Standards Agency. Available online: http://www.food.gov.uk/business-guidance/novelfoods (accessed on 1 August 2021).

18. Japan. Food Additives. Ministry of Health, Labour and Welfare. Available online: https://www.mhlw.go.jp/stf/seisakunitsuite /bunya/kenkou_iryou/shokuhin/syokuten/index_00012.html (accessed on 1 August 2021).

19. Japan. Food. Ministry of Health, Labour and Welfare. Available online: https://www.mhlw.go.jp/english/topics/foodsafety/ (accessed on 1 August 2021). 
20. Australia. Food Standards Australia New Zealand: Application Handbook. Food Standards Australia New Zealand. 2016. Available online: https:/ / www.foodstandards.gov.au/code/changes/pages/applicationshandbook.aspx (accessed on 1 August 2021).

21. Canada. The Food Directorate's Pre-Market Submission Management Process for Food Additives, Infant Formulas and Novel Foods. Health Canada. 2016. Available online: https://www.canada.ca/en/health-canada/services/food-nutrition/public-invo lvement-partnerships/food-directorate-market-submission-management-process-food-additives-infant-formulas-novel-food s.html (accessed on 1 August 2021).

22. Canada. Food Additive Submission Checklist. 2008. Available online: https://www.canada.ca/en/health-canada/services/food -nutrition/reports-publications/appendix-food-additive-submission-checklist-guide-preparation-submissions-food-additiv es.html (accessed on 1 August 2021).

23. Food and Consumer Products of Canada. Industry Sustainability and Competitiveness Study. Available online: https://www.fc pc.ca/Industry-Resources/Industry-Sustainability-Competitiveness-Study (accessed on 1 August 2021).

24. United States. Ingredients, Additives, GRAS \& Packaging Guidance Documents \& Regulatory Information. Food and Drug Administration. 2019. Available online: http:/ / www.fda.gov/food/guidance-documents-regulatory-information-topic-foodand-dietary-supplements/ingredients-additives-gras-packaging-guidance-documents-regulatory-information (accessed on 1 August 2021).

25. United States. Guidance for Industry: Questions and Answers about the Food Additive or Color Additive Petition Process. Food and Drug Administration. 2020. Available online: http://www.fda.gov/regulatory-information/search-fda-guidance -documents/guidance-industry-questions-and-answers-about-food-additive-or-color-additive-petition-process (accessed on 1 August 2021).

26. Mexico. Los más Buscado. Government of Mexico. Available online: https://www.gob.mx/tramites (accessed on 1 August 2021).

27. Canada. Centre of Administration for Permissions. Canadian Food Inspection Agency. 2015. Available online: https: //inspection.gc.ca/about-the-cfia/permits-licences-and-approvals/centre-of-administration-for-permissions/eng/139534858 3779/1395348638922 (accessed on 1 August 2021).

28. Canada. Regulatory Readiness: A Decision Model for Canadian Food Products. Agriculture and Agri-Food Canada. 2011. Available online: http:/ / www.agr.gc.ca/eng/industry-markets-and-trade/canadian-agri-food-sector-intelligence/processedfood-and-beverages / trends-and-market-opportunities-for-the-food-processing-sector/regulatory-readiness-a-decision-mo del-for-canadian-food-products / ?id=1311966040606 (accessed on 1 August 2021).

29. Canada. Canada's Regulatory System for Foods with Health Benefits: An Overview for Industry. Agriculture and Agri-Food Canada. 2010. Available online: http://www.agr.gc.ca/eng/industry-markets-and-trade/canadian-agri-food-sector-intellige nce/processed-food-and-beverages / trends-and-market-opportunities-for-the-food-processing-sector/canada-s-regulatorysystem-for-foods-with-health-benefits-an-overview-for-industry/?id=1274467299466 (accessed on 1 August 2021).

30. Canada. Novel Foods. Health Canada. 2010. Available online: https://www.canada.ca/en/health-canada/services/food-nutri tion/genetically-modified-foods-other-novel-foods/factsheets-frequently-asked-questions/novel-foods.html (accessed on 1 August 2021).

31. Hale, G. Regulatory system in North America: Diplomacy navigating asymmetries. Am. Rev. Can. Stud. 2019, 1, 123-149. [CrossRef]

32. European Food Safety Authority. Novel Food. Available online: https://www.efsa.europa.eu/en/topics/topic/novel-food (accessed on 1 August 2021).

33. Germany. Federal Ministry of Food and Agriculture. Federal Ministry of Food and Agriculture. Available online: https: //www.bmel.de/EN/Homepage/homepage_node.html (accessed on 1 August 2021).

34. Germany. Novel Food. Available online: https://www.bfr.bund.de/en/novel_food-1809.html (accessed on 1 August 2021).

35. Netherlands. Food Safety Requirements. Government of the Netherlands. Available online: https://www.government.nl/topics / food/food-safety-requirements (accessed on 1 August 2021).

36. Ellwood, K.; Finley, J.W.; Hoadley, J. Launching a new food product or dietary supplement in the United States: Industrial, regulatory, and nutritional considerations. Annu. Rev. Nutr. 2014, 34, 421-447. [CrossRef]

37. Japan. Implementation of Imported Foods Monitoring Plan for FY 2019. Ministry of Health, Labour and Welfare. Available online: https:/ / www.mhlw.go.jp/english/topics/importedfoods/19/index.html (accessed on 1 August 2021).

38. Italy. Istituto Zooprofilattico Sperimentale del Lazio e Della Toscana. Available online: http://www.izslt.it/eng/food-safety/\% 0ahttp:/www.salute.gov.it/portale/p5_0.jsp?lingua=italiano\&id=52 (accessed on 1 August 2021).

39. France. Novel Foods and Food Ingredients. French Agency for Food, Environmental and Occupational Health \& Safety. Available online: https:/ / www.anses.fr/en/content/novel-foods-and-food-ingredients (accessed on 1 August 2021).

40. Mexico. Comisión Federal Para la Protección Contra Riesgos Sanitarios. Comisión Federal Para la Protección Contra Riesgos Sanitarios. Available online: https: / / www.gob.mx/cofepris (accessed on 1 August 2021).

41. Steier, G. The carbon tax vacuum and the debate about climate change: Emission taxation of commodity crop production in food system regulation. Pace Environ. Law Rev. 2018, 35, 346-374.

42. Canada. Consolidated Federal Laws of Canada, Pest Control Products Act. Justice Laws Canada. 2019. Available online: https:/ /laws-lois.justice.gc.ca/eng/acts/P-9.01/ (accessed on 1 August 2021). 
43. Canada. Consolidated Federal Laws of Canada, New Substances Notification Regulations (Organisms). Justice Laws Canada. 2018. Available online: https://laws-lois.justice.gc.ca/eng/regulations/SOR-2005-248/index.html (accessed on 1 August 2021).

44. Canada. Pollution Pricing. Environment and Climate Change Canada. 2018. Available online: https://www.canada.ca/en/envir onment-climate-change/services/climate-change/pricing-pollution-how-it-will-work.html (accessed on 1 August 2021).

45. Canada. Managing and Reducing Waste. Environment and Climate Change Canada. 2017. Available online: https://www.cana da.ca/en/services/environment/pollution-waste-management/managing-reducing-waste.html (accessed on 1 August 2021).

46. Canada. Water Overview. Environment and Climate Change Canada. 2017. Available online: https://www.canada.ca/en/envir onment-climate-change/services/water-overview.html (accessed on 1 August 2021).

47. Canada. Management of Hazardous Waste and Hazardous Recyclable Material. Environment and Climate Change Canada. 2010. Available online: https:/ / www.canada.ca/en/environment-climate-change/services/managing-reducing-waste/permit-ha zardous-wastes-recyclables/management.html (accessed on 1 August 2021).

48. Canada. Wastewater Systems Effluent Regulations. Available online: https://laws-lois.justice.gc.ca/eng/regulations/SOR-2012 -139/FullText.html (accessed on 1 August 2021).

49. United States. Tonnage of Top 50 US Water Ports, Ranked by Total Tons. Bureau of Transportation Statistics, US Department of Transport. 2018. Available online: https://www.bts.gov/content/tonnage-top-50-us-water-ports-ranked-total-tons (accessed on 1 August 2021).

50. United States. Summary of the Food Quality Protection Act. United States Environmental Protection Agency. 2015. Available online: https: / / www.epa.gov/laws-regulations/summary-food-quality-protection-act (accessed on 1 August 2021).

51. United States. About the Office of Water. United States Environmental Protection Agency. 2013. Available online: https: //www.epa.gov/aboutepa/about-office-water (accessed on 1 August 2021).

52. United States. Guidelines for the Storage and Collection of Residential, Commercial, and Institutional Solid Waste. Electronic Code of Federal Regulations. Available online: https: / / www.ecfr.gov / cgi-bin/retrieveECFR?gp=\&SID=c94567294dff611654af7 a3944a91d69\&mc=true\&r=PART\&n=pt40.27.243 (accessed on 1 August 2021).

53. European Union Law. European Parlaiment and Council Directive on Packaging and Packaging Waste (31994L0062-EN26.05.2015). Available online: https:/ / eur-lex.europa.eu/legal-content/EN/TXT/HTML/?uri=CELEX:01994L0062-20150526\& from $=\mathrm{EN}$ (accessed on 1 August 2021).

54. Netherlands. Information from the Government of the Netherlands. Governemtn of the Netherlands. 2013. Available online: https: / /www.government.nl/ (accessed on 1 August 2021).

55. Netherlands. Government-Wide Programme for a Circular Economy. Government of the Netherlands. Available online: https:/ / www.government.nl/documents/letters/2016/09/14/government-wide-programme-for-a-circular-economy (accessed on 1 August 2021).

56. Australia. Find, Explore and Reuse Australia's Public Data. Australian Government. Available online: https://data.gov.au (accessed on 1 August 2021).

57. Australia. Food Regulation System. Department of Health. Available online: https://www1.health.gov.au/internet/publications /publishing.nsf/Content/foodsecretariat-stakeholder-engagement-toc \{ $\} 4$ (accessed on 1 August 2021).

58. United Kingdom. Carbon Emissions Tax. Available online: https://www.gov.uk/government/publications/carbon-emmisionstax/carbon-emmisions-tax (accessed on 1 August 2021).

59. United Kingdom. Packaging (Essential Requirements) Regulations: Guidance Notes. Available online: https://www.gov.uk/gov ernment/publications/packaging-essential-requirements-regulations-guidance-notes (accessed on 1 August 2021).

60. Germany. Waste Management in Germany 2018: Facts, Data, Diagrams. 2018. Available online: https://www.bmu.de/fileadmin /Daten_BMU /Pools/Broschueren/abfallwirtschaft_2018_en_bf.pdf (accessed on 1 August 2021).

61. Germany. Federal Ministry for the Environment, Nature Conservation and Nuclear Safety Germany. Federal Ministry for the Environment, Nature Conservation and Nuclear Safety. Available online: https://www.bmu.de/en/ (accessed on 1 August 2021).

62. France. Ministry of Ecological and Solidarity Transition. Ministry of Ecological and Solidarity Transition. Available online: https:/ / www.ecologique-solidaire.gouv.fr/en (accessed on 1 August 2021).

63. Japan. Waste \& Recycling. Ministry of the Environment. Available online: http://www.env.go.jp/en/recycle/index.html (accessed on 1 August 2021).

64. Qasim, H.; Liang, Y.; Guo, R.; Saeed, A.; Badar, N.A. The defining role of environmental self-identity among consumption values and behavioral intention to consume organic food. Int. J. Environ. Res. Public Health 2019, 16, 1106. [CrossRef]

65. Canada. Canadian Environmental Protection Act Registry. Environment and Climate Change Canada. 2007. Available online: http s:/ / www.canada.ca/en/environment-climate-change/services/canadian-environmental-protection-act-registry.html (accessed on 1 August 2021).

66. United States. Title 40: Protection of the Environment. Electronic Code of Federal Regulations. Available online: https://www.ec fr.gov / cgi-bin / retrieveECFR?gp=1\&SID=287870523535af49d3562aec528d94c9\&ty=HTML\&h=L\&n=40y17.0.1.1.4\&r=PART (accessed on 1 August 2021).

67. United Kingdom. Guidelines for Environmental Risk Assessment and Management: Green Leaves III. Available online: https: //www.gov.uk/government/publications/guidelines-for-environmental-risk-assessment-and-management-green-leaves-iii (accessed on 1 August 2021). 
68. United Kingdom. Waste and Environmental Impact. Available online: https://www.gov.uk/browse/business/waste-environme nt (accessed on 1 August 2021).

69. Environmental Law Alliance Worldwide. Act on the Prevention of Harmful Effects on the Environment Caused by Air Pollution, Noise, Vibration and Similar Phenomena. 2002. Available online: https://www.elaw.org/content/germany-act-prevention-ha rmful-effects-environment-caused-air-pollution-noise-vibration-and- (accessed on 1 August 2021).

70. Environmental Law Alliance Worldwide. Federal Water Act. 2002. Available online: https://elaw.org/content/germany-federal -water-act-19-august-2002 (accessed on 1 August 2021).

71. Japan. Agricultural Chemicals Regulation. Food and Agricultural Materials Inspection Center. Available online: http://www.ac is.famic.go.jp/eng/hourei/regulation_law.htm (accessed on 1 August 2021).

72. Japan. Health \& Chemicals. Ministry of the Environment. Available online: http://www.env.go.jp/en/chemi/index.html (accessed on 1 August 2021).

73. Water Environment Partnership in Asia. Water Pollution Control Law. Available online: http://www.wepa-db.net/policies/law /japan/wpctop.htm (accessed on 1 August 2021).

74. Australia. Food and Medicine Regulation. Department of Health. 2014. Available online: https://www.tga.gov.au/community-q a/food-and-medicine-regulation (accessed on 1 August 2021).

75. Netherlands. Environmental Management Act. Ministry of Housing, Spatial Planning and the Environment. 2004. Available online: https://www.asser.nl/upload/eel-webroot/www/documents/national/netherlands/EMA052004.pdf (accessed on 1 August 2021).

76. Observatory of Economic Complexity. Italy (ITA) Exports, Imports, and Trade Partners. The Observatory of Economic Complexity. Available online: https://oec.world/en/profile/country/ita/ (accessed on 1 August 2021).

77. Observatory of Economic Complexity. Canada (CAN) Exports, Imports, and Trade Partners. Available online: https://oec.worl $\mathrm{d} / \mathrm{en} /$ profile/country/can/ (accessed on 1 August 2021).

78. Observatory of Economic Complexity. Mexico (MEX) Exports, Imports, and Trade Partners. Observatory of Economic Complexity. Available online: https://oec.world/en/profile/country/mex/ (accessed on 1 August 2021).

79. Observatory of Economic Complexity. France (FRA) Exports, Imports, and Trade Partners. Observatory of Economic Complexity. Available online: https://oec.world/en/profile/country/fra/ (accessed on 1 August 2021).

80. Observatory of Economic Complexity. Netherlands (NLD) Exports, Imports, and Trade Partners. Observatory of Economic Complexity. Available online: https://oec.world/en/profile/country/nld/ (accessed on 1 August 2021).

81. Observatory of Economic Complexity. Australia (AUS) Exports, Imports, and Trade Partners. Observatory of Economic Complexity. Available online: https://oec.world/en/profile/country/aus/(accessed on 1 August 2021).

82. Observatory of Economic Complexity. United States (USA) Exports, Imports, and Trade Partners. Observatory of Economic Complexity. Available online: https://oec.world/en/profile/country/usa/ (accessed on 1 August 2021).

83. Observatory of Economic Complexity. United Kingdom (GBR) Exports, Imports, and Trade Partners. The Observatory of Economic Complexity. Available online: https://oec.world/en/profile/country/gbr (accessed on 1 August 2021).

84. Observatory of Economic Complexity. Germany (DEU) Exports, Imports, and Trade Partners. Observatory of Economic Complexity. Available online: https://oec.world/en/profile/country/deu/ (accessed on 1 August 2021).

85. Observatory of Economic Complexity. Japan (JPN) Exports, Imports, and Trade Partners. Observatory of Economic Complexity. Available online: https://oec.world/en/profile/country/jpn/ (accessed on 1 August 2021).

86. Canada. Consumer Price Index, Annual Average, Not Seasonally Adjusted (Table: 18-10-0005-01). Statistics Canada. 2020. Available online: https://www150.statcan.gc.ca/t1/tbl1/en/tv.action?pid=1810000501 (accessed on 1 August 2021).

87. Germany. Short-Term Indicators: Consumer Price Index for Germany, Food and Non-Alcoholic Beverages. Statistisches Bundesamt. 2020. Available online: https://www.destatis.de/EN/Themes/Economy/Short-Term-Indicators/Basic-Data/vpi 001j.html;jsessionid=760218DD610D832C2CEA16500E445580.internet8711 (accessed on 1 August 2021).

88. France. Consumer Price Index_Base 2015-All Households_France-Food (Identifier 001759963). Institut National de la Statistique et des Études Économiques. 2020. Available online: https: / /www.insee.fr/en/statistiques/serie/001759963\#Tableau (accessed on 1 August 2021).

89. United States. March 25, 2020 Forecast: Consumer Price Indexes (Not Seasonally Adjusted) and Forecasts by USDA, Economic Research Service. US Bureau of Labor Statistics. 2020. Available online: https://www.bls.gov/cpi/tables/home.htm (accessed on 1 August 2021).

90. Australia. Consumer Price Index, Australia (6401.0, Dec 2019). Australian Bureau of Statistics. 2019. Available online: https: //www.abs.gov.au/AUSSTATS/abs@.nsf/DetailsPage/6401.0Dec\%202019?OpenDocument (accessed on 1 August 2021).

91. Netherlands. Consumer Prices; Price Index 2015=100. CBS Statistics Netherlands. 2020. Available online: https://opendata.cbs.n 1/statline/\#/CBS/en/dataset/83131eng/table?ts=158619811027 (accessed on 1 August 2021).

92. United Kingdom. Consumer Price Inflation Timer Series. Office for National Statistics. 2020. Available online: https:/ / www.ons. gov.uk/economy/inflationandpriceindices/datasets/consumerpriceindices (accessed on 1 August 2021).

93. Federal Reserve Bank of St. Louis. Consumer Price Index: Food for Mexico. Federal Reserve Bank of St. Louis. 2020. Food and Consumer Products of Canada. Growth and Innovation. Available online: https://www.fcpc.ca/Priorities-Policy/Growth-Innov ation (accessed on 1 August 2021). 
94. Italy. Ufficio Italiano Brevetti e Marchi. Ministero Dello Sviluppo Economico. Available online: https://uibm.mise.gov.it/index.p $\mathrm{hp} /$ it/ (accessed on 1 August 2021).

95. Organization for Economic Co-Operation and Development. GDP per Hour Worked (Labour Productivity). Organization for Economic Co-Operation and Development. 2020. Available online: https://data.oecd.org/lprdty/gdp-per-hour-worked.htm (accessed on 1 August 2021).

96. Organization for Economic Co-Operation and Development. Long-Term Interest Rates. Organization for Economic Co-Operation and Development. 2020. Available online: https:/ / data.oecd.org/interest/long-term-interest-rates.htm (accessed on 1 August 2021).

97. Consumer Price Index: Food for Mexico. Available online: https:/ / fred.stlouisfed.org/series /MEXCPIFODAINMEI (accessed on 1 August 2021).

98. World Economic Forum. Global Competitiveness Report 2019. Available online: https://www.weforum.org/reports/global-com petitiveness-report-2019/ (accessed on 1 August 2021).

99. Bank of Canada. Currency Converter. Bank of Canada. 2020. Available online: https://www.bankofcanada.ca/rates/exchange/c urrency-converter/ (accessed on 1 August 2021).

100. Canada. Canadian Agricultural Partnership. Agriculture and Agri-Food Canada. 2019. Available online: http:/ /www.agr.gc.ca/ eng/about-our-department/key-departmental-initiatives/canadian-agricultural-partnership/?id=1461767369849 (accessed on 1 August 2021).

101. Canada. Strategic Innovation Fund: About the Program. Innovation, Science and Economic Development Canada. 2019. Available online: http://www.ic.gc.ca/eic/site/125.nsf/eng/00023.html (accessed on 1 August 2021).

102. Canada. The Government of Canada Invests in Innovation to Advance Canada's Food Processing. Agriculture and Agri-Food Canada. 2019. Available online: https:/ /www.canada.ca/en/agriculture-agri-food/news/2019/08/the-government-of-cana da-invests-in-innovation-to-advance-canadas-food-processing.html (accessed on 1 August 2021).

103. United Kingdom. Guidance: State Aid for Agriculture and Fisheries. Department for Environment, Food \& Rural Affairs. 2020. Available online: https:// www.gov.uk/guidance/state-aid-for-agriculture-and-fisheries\#public-money-spend-the-process (accessed on 1 August 2021).

104. United Kingdom. Guidance: UK Seafood Innovation Fund. Department for Environment, Food \& Rural Affairs. 2020. Available online: https:/ / www.gov.uk/guidance/uk-seafood-innovation-fund (accessed on 1 August 2021).

105. United Kingdom. Farmers Affected by This Summer's Flooding Can Now Apply for Support through the Farming Recovery Fund. Department for Environment, Food \& Rural Affairs. 2019. Available online: https:/ /www.gov.uk/government/news/def ra-opens-2-million-fund-to-restore-flood-affected-farmland (accessed on 1 August 2021).

106. Germany. 27th Subsidy Report: 2017-2020. Federal Ministry of Finance. 2020. Available online: https://www.bundesfinanzminis terium.de/Content/EN/Standardartikel/Press_Room/Publications/Brochures/2020-03-03-27subsidy-report.pdf?_blob=pu blicationFile\&v=4 (accessed on 1 August 2021).

107. Germany. Agricultural policy: More Cash for Sustainable Agriculture. Federal Government of Germany. 2020. Available online: https:/ / www.bundesregierung.de/breg-en/search/nachhaltige-landwirtschaft-1667612 (accessed on 1 August 2021).

108. France. The State Budget. Ministère de l'Économie et des Finances. 2020. Available online: https://www.aft.gouv.fr/en/state-b udget\#PLF (accessed on 1 August 2021).

109. France. French Agri-Food Industries. Ministère de l'Agriculture et de l'Alimentation. 2018. Available online: https://agriculture. gouv.fr/french-agri-food-industries-2018 (accessed on 1 August 2021).

110. France. The Big Investment Plan 2018-2022. Government of France. Available online: https://www.gouvernement.fr/en/the-b ig-investment-plan-2018-2022 (accessed on 1 August 2021).

111. European Union. (2017, April 7). Italy Launches New Financial Instrument to Support Agriculture Using EU Funds. European Union. Available online: https:/ / ec.europa.eu/info/news/italy-launch-new-financial-instrument-agriculture-supported-eu-f unds-2017-apr-07_en (accessed on 1 August 2021).

112. Italy. Home Page. Ministero delle Politiche Agricole Alimentary e Forestali. Available online: https://www.politicheagricole.it/f lex/cm/pages/ServeBLOB.php/L/IT/IDPagina/202 (accessed on 1 August 2021).

113. Japan. A Guide to Japan's Aid. Government of Japan. Available online: https://www.mofa.go.jp/policy/oda/guide/1998/1-6.h tml (accessed on 1 August 2021).

114. Netherlands. (2017, December 14). Government Wants $€ 75$ Million for Young Farmers. Government of the Netherlands. Available online: https:/ / www.government.nl/topics/agriculture/news/2017/12/14/government-wants-€75-million-for-young-farmers (accessed on 1 August 2021).

115. Netherlands. Funding of European Grants. Government of the Netherlands. Available online: https://www.government.nl/topi cs/european-grants (accessed on 1 August 2021).

116. United States. Agriculture and Food Research Initiative. National Institute of Food and Agriculture. 2020. Available online: https:/ / nifa.usda.gov/program/agriculture-and-food-research-initiative-afri (accessed on 1 August 2021).

117. United States. Beginning Farmer and Rancher Development Program. National Institute of Food and Agriculture. 2020. Available online: https:/ / nifa.usda.gov/funding-opportunity/beginning-farmer-and-rancher-development-program-bfrdp (accessed on 1 August 2021). 
118. United States. Community Food Projects (CFP) Competitive Grants Program. National Institute of Food and Agriculture. 2020. Available online: https:/ / nifa.usda.gov/funding-opportunity/community-food-projects-cfp-competitive-grants-program (accessed on 1 August 2021).

119. United States. Food Safety Outreach Program. National Institute of Food and Agriculture. 2020. Available online: https: //nifa.usda.gov/funding-opportunity/food-safety-outreach-program (accessed on 1 August 2021).

120. United States. Search for a Funding Opportunity. National Institute of Food and Agriculture (US Department of Agriculture). 2020. Available online: https:/ / nifa.usda.gov/page/search-grant (accessed on 1 August 2021).

121. Australia. Current Grants and Assistance. Department of Agriculture, Water and the Environment. 2019. Available online: https://www.agriculture.gov.au/ag-farm-food/drought/assistance/other-assistance (accessed on 1 August 2021).

122. Australia. Grants and Programs: Agriculture. Business. Available online: https://www.business.gov.au/SearchResult?query=a griculture\&type $=1$ (accessed on 1 August 2021).

123. Organization for Economic Co-Operation and Development. Foreign Direct Investment for Development: Maximising Benefits, Minimising Costs. 2002. Available online: https://www.oecd.org/investment/investmentfordevelopment/foreigndirectinvest mentfordevelopmentmaximisingbenefitsminimisingcosts.htm (accessed on 1 August 2021).

124. Edeka. Aktuelle Geschaftsberichte. Edeka. 2020. Available online: https://verbund.edeka/unternehmen/daten-fakten/berichte/ (accessed on 1 August 2021).

125. Germany. More than 60 Billion Euros Revenue for the First Time. Rewe Group. 2019. Available online: https://www.rewe-group .com/en/newsroom/press-releases/1686-rewe-group-experiences-strong-national-and-international-growth (accessed on 1 August 2021).

126. Metro. Annual report 2018/19: Consolidated Financial Statements. Metro. 2019. Available online: https://reports.metroag.de/a nnual-report/2018-2019/servicepages/downloads.html (accessed on 1 August 2021).

127. Rewe Group. Rewe Group Annual Report 2018. Rewe Group. 2018. Available online: https:/ /www.rewe-group-geschaeftsberic ht.de/en/home/index.html (accessed on 1 August 2021).

128. Lidl. Number of Stores. Lidl. Available online: https://unternehmen.lidl.de/about-lidl (accessed on 1 August 2021).

129. United States. Germany Retail Foods 2018. Foreign Agricultural Service. 2018. Available online: https://apps.fas.usda.gov/ne wgainapi/api/report/downloadreportbyfilename?filename=Retail\%20Foods_Berlin_Germany_4-17-2018.pdf (accessed on 1 August 2021).

130. Asda Group Ltd. Asda Group Publishes Annual Statutory Accounts. Asda Group Ltd. 2018. Available online: https://corporate asda.com/newsroom/2019/09/16/asda-group-limited-publishes-annual-statutory-accounts (accessed on 1 August 2021).

131. John Lewis Partnership. The Partnership Difference: John Lewis Partnership PLC Annual Report and Accounts 2019. John Lewis Partnership. 2019. Available online: https:/ / www.johnlewispartnership.co.uk/content/dam/cws/pdfs/financials/annual-r eports/john-lewis-partnership-annual-report-and-accounts-2019.pdf (accessed on 1 August 2021).

132. Jolly, J. (2020, January 6). Aldi Sales Reach Record $£ 1$ bn at Christmas as It Opens More Stores. The Guardian. Available online: https:/ / www.theguardian.com/business/2020/jan/06/aldi-sales-christmas-stores (accessed on 1 August 2021).

133. Kantar. Great Britain: Grocery Market Share. Kantar. 2020. Available online: https://www.kantarworldpanel.com/grocery-mar ket-share/great-britain (accessed on 1 August 2021).

134. Lidl GB. Our History. Lidl GB. Available online: https://www.lidl.co.uk/about-us (accessed on 1 August 2021).

135. Morrisons Corporate. 2018/19 Investor Financial Report. Morrisons Corporate. 2019. Available online: https://www.morrisonscorporate.com/investor-centre/financial-reports/ (accessed on 1 August 2021).

136. Sansbury's. Annual Report and Financial Statements 2019. Sansbury's. 2019. Available online: https://www.about.sainsburys.co uk/investors/annual-report-2019 (accessed on 1 August 2021).

137. Tesco. Annual Report and Financial Statements 2019. Tesco. 2019. Available online: https://www.tescoplc.com/investors/repor ts-results-and-presentations/annual-report-2019/ (accessed on 1 August 2021).

138. Costco Wholesale. 2019 Annual Report. Costco Wholesale. 2019. Available online: https://investor.costco.com/static-files/05c62 fe6-6c09-4e16-8d8b-5e456e5a0f7e (accessed on 1 August 2021).

139. Empire Company Limited. Empire Company Finishes Fiscal 2019 with Strong Sales and Earnings; Exceeds Sunrise Targets; Announces 9\% Dividend Increase and Share Buyback. 2019. Available online: https://corporate.sobeys.com/wp-content/uplo ads/2019/06/Empire-Q4-F19-News-Release-SEDAR-EN.pdf (accessed on 1 August 2021).

140. Loblaw Companies Ltd. Live Life Well: 2019 Annual Report. 2019. Available online: https://s1.q4cdn.com/326961052/files/doc financials/2019/ar/6573_LCL_ENG_AR2019_Complete_AODA.pdf (accessed on 1 August 2021).

141. Metro. Shareholder Information: Financial Information. 2020. Available online: https://corpo.metro.ca/en/investor-relations.h tml (accessed on 1 August 2021).

142. Sobeys Corporate. Our Stores and Businesses: At a Glance. Available online: https://corporate.sobeys.com/at-a-glance/ (accessed on 1 August 2021).

143. United States. Canada-Retail Foods-Retail Sector Overview 2018. USDA Foreign Agricultural Service. 2018. Available online: https://apps.fas.usda.gov/newgainapi/api/report/downloadreportbyfilename?filename=Retail\%20Foods_Ottawa_ Canada_6-26-2018.pdf (accessed on 1 August 2021).

144. Walmart Inc. 2020 Annual Report. Walmart Inc. 2020. Available online: https://s2.q4cdn.com/056532643/files/doc_financials/ 2020/ar/Walmart_2020_Annual_Report.pdf (accessed on 1 August 2021). 
145. Walmart Inc. Defining the Future of Retail. Part I, Item 2, Chart 2. Walmart Inc. 2019, p. 26. Available online: https: //s2.q4cdn.com/056532643/files/doc_financials/2019/annual/Walmart-2019-AR-Final.pdf (accessed on 1 August 2021).

146. Aldi. ALDI Merken. Aldi. Available online: https://www.aldi.nl/onze-producten/aldi-merken.html (accessed on 1 August 2021).

147. Carrefour Group. 2019 Full-Year Results Presentation. Carrefour Group. 2020. Available online: https://www.carrefour.com/en /newsroom/2020/2019-full-year-results-presentation (accessed on 1 August 2021).

148. Carrefour Group. Financial Publications: Sales and Results 2019, Full-Year Financial Results. Carrefour. 2019. Available online: https:/ / www.carrefour.com/en/finance/financial-publications (accessed on 1 August 2021).

149. Carrefour Group. All Our Store Formats. Carrefour Group. Available online: https://www.carrefour.com/en/group/stores (accessed on 1 August 2021).

150. E.Leclerc. 2019 Confronte la Stratégie Commerciale d'E.Leclerc et Annonce Une Croissance Solide Pour les 3 Prochaines Années E.Leclerc. 2020. Available online: https:/ / www.mouvement.leclerc/2019-conforte-la-strategie-commerciale-deleclerc-et-anno nce-une-croissance-solide-pour-les-3 (accessed on 1 August 2021).

151. European Supermarket Magazine. (2020, March 9). Les Mousquetaires Sees 2.1\% Growth in Turnover in FY2019. European Supermarket Magazine. Available online: https:/ /www.esmmagazine.com/retail/les-sees-2-1-growth-in-turnover-in-fy2019-9 1864 (accessed on 1 August 2021).

152. Germany. Federal Data Protection Act (BDSG). Bundesministerium der Justiz und Fur Verbraucherschutz. Available online: https: //www.gesetze-im-internet.de/englisch_bdsg/ (accessed on 1 August 2021).

153. Aldi. Find Your Local Aldi. Aldi. Available online: http://storelocator.aldi.com.au/Presentation/AldiSued/en-au/Start (accessed on 1 August 2021).

154. Australian United Retailers Ltd. Annual Report 2018/2018 Financial Year. Australian United Retailers Ltd. 2019. Available online: https:/ / foodworks.com.au/file/preview /b558f1cb-7ad7-4fe0-94bf-19c0bb9505cc/AURL_2019_Financial_Statements.pdf (accessed on 1 August 2021).

155. Chung, F. Aldi Launches Biggest Brand Overhaul in 16 years, Vows to Maintain Price Leadership or 'We're Dead'. News.com.au. 15 May 2017. Available online: https://www.news.com.au/finance/business/retail/aldi-launches-biggest-brand-overhaul-in -16-years-vows-to-maintain-price-leadership-or-were-dead/news-story /6459bc21121c7f9160c1d9a40e30b99d (accessed on 1 August 2021).

156. Coles Group. 2019 Annual Report. Coles Group. 2019. Available online: https://www.colesgroup.com.au/FormBuilder/_Resou rce/_module/ir5sKeTxxEOndzdh00hWJw / file/Coles_Annual_Report_2019.pdf (accessed on 1 August 2021).

157. Groupe Casino. Continuons d'innover pour le Commerce de Domain: Document de Référence 2018. Groupe Casino. 2018. Available online: https:/ / www.groupe-casino.fr/wp-content/uploads/2019/04/Groupe-Casino-DDR-2018.pdf (accessed on 1 August 2021).

158. IGA. Get a Taste for Shopping Independent. IGA. Available online: http:/ / our-stores.iga.com.au (accessed on 1 August 2021).

159. Metcash. Investing for Growth: Metcash Annual Report 2019. Metcash. 2019. Available online: https://mars-metcdn-com.global .ssl.fastly.net/content/uploads/sites/101/2019/07/26111329/Metcash-Annual-Report-2019.pdf (accessed on 1 August 2021).

160. Roy Morgan. (2019, April 5). Woolworths and Aldi Grow Grocery Market Share in 2018. Roy Morgan. Available online: http:/ / www.roymorgan.com/ findings/7936-australian-grocery-market-december-2018-201904050426 (accessed on 1 August 2021).

161. Woolworths Group. Better Together: 2019 Annual Report. Woolworths Group. 2019. Available online: https://www.woolworths group.com.au/icms_docs/195582_annual-report-2019.pdf (accessed on 1 August 2021).

162. Woolworths Group. Australian Food: Woolworths Supermarkets. Woolworths Group. Available online: https://www.woolwort hsgroup.com.au/page/about-us/our-brands/supermarkets/Woolworths (accessed on 1 August 2021).

163. Ahold Delhaize. Eat well, Save Time, Live Better: Annual Report 2019. Ahold Delhaize. 2019. Available online: https: / / www.aholddelhaize.com/media/10197/ahold-delhaize-annual-report-2019.pdf (accessed on 1 August 2021).

164. Ahold Delhaize. Albert Heijn: Did You Know. Ahold Delhaize. Available online: https://www.aholddelhaize.com/en/brands/ netherlands/albert-heijn/ (accessed on 1 August 2021).

165. Coop. Coop Groeit Ook in 2019 Stevig Door. Coop. 2019. Available online: https://www.coop.nl/over-coop/coop-groeit-ook-in -2019-stevig-door (accessed on 1 August 2021).

166. Coop. Jaarveslag Coop 2019. Coop. 2019. Available online: https://view.publitas.com/coop-supermarkten/coop-jaarverslag-2 019/page/82-83 (accessed on 1 August 2021).

167. Coop. Coop Organization. Coop. Available online: https://www.coop.nl/over-coop/coop-als-organisatie (accessed on 1 August 2021).

168. Detailresult Groep. Organisatie. Detailresult Groep. Available online: https://www.detailresult.nl/over-ons/organisatie (accessed on 1 August 2021).

169. Detailresult Groep. Over Ons. Detailresult Groep. Available online: https://www.detailresult.nl/over-ons (accessed on 1 August 2021).

170. Jumbo. 2019 Jumbo Formule Ziet Omzet Met Ruim 1 Miljard Stijgen. Jumbo. 2019. Available online: https://www.jumborapport age.com/in-het-kort/ (accessed on 1 August 2021). 
171. Jumbo. Toelichting Kerngegevens. Jumbo. 2019. Available online: https://www.jumborapportage.com/jaarverslagen/2019/cor porate-jaarverslag/kerngegevens/toelichting-kerngegevens (accessed on 1 August 2021).

172. Lidl. Lidl Nederland. Lidl. Available online: https:/ / corporate.lidl.nl/?_ga=2.154771128.1251652950.1587940977-251429966.158 7940977 (accessed on 1 August 2021).

173. Aeon Co., Ltd. Aeon Review 2018: Financial Information. Aeon Co., Ltd. 2018. Available online: https://ssl4.eir-parts.net/doc/8 267/ir_material_for_fiscal_ym13/54508/00.pdf (accessed on 1 August 2021).

174. Maruetsu. 2018 Corporate Profile. Shiawaseikatsu, Maruetsu. 2018. Available online: https://www.maruetsu.co.jp/corporate/p df/2018_kaishaannai_english.pdf (accessed on 1 August 2021).

175. Life. Home. Life. Available online: http://www.lifecorp.jp/company/ir/library/archive.html (accessed on 1 August 2021).

176. Seijo Ishii. About Us: Business. Seijo Ishii. Available online: http:/ /www.seijoishii.co.jp/en/business/ (accessed on 1 August 2021).

177. Albertsons Companies. Albertsons Companies Inc., Reports Fourth Quarter and Full Year Results. Albertsons Companies. 2018. Available online: https:/ /last10k.com/sec-filings/1646972 (accessed on 1 August 2021).

178. Kroger. 2018 Kroger Fact Book. 2018. Available online: http://ir.kroger.com/Cache/IRCache/a6a0a700-fddd-d4a0-ad3e-c2e12b 070cf9.PDF?O=PDF\&T=\&Y=\&D=\&FID=a6a0a700-fddd-d4a0-ad3e-c2e12b070cf9\&iid=4004136 (accessed on 1 August 2021).

179. Peterson, H. The Grocery Wars Are Intensifying with Walmart and Kroger in the Lead and Amazon Poised to 'Cause Disruption'. Business Insider Singapore. 2020. Available online: https:/ / www.businessinsider.sg/walmart-kroger-dominate-us-grocery-am azon-gains-share-2020-1 (accessed on 1 August 2021).

180. Redman, R. Ahold Delhaize Closes out Fiscal Year on an up Note. Supermarket News. 27 February 2019. Available online: https:/ / www.supermarketnews.com/retail-financial/ahold-delhaize-closes-out-fiscal-year-note (accessed on 1 August 2021).

181. United States. Retail Trends. Economic Research Service, United States Department of Agriculture. 2019. Available online: https:/ / www.ers.usda.gov/topics/food-markets-prices/retailing-wholesaling/retail-trends/ (accessed on 1 August 2021).

182. United States. The Dutch Food Retail Report 2019. U.S. Foreign Agricultural Service. 2019. Available online: https: / /apps.fas.usda.gov/newgainapi/api/report/downloadreportbyfilename?filename=Retail\%20Foods_The\%20Hague_Netherl ands_6-26-2019.pdf (accessed on 1 August 2021).

183. Walmart Inc. 2019 Annual Report: Defining the Future of Retail. Part I, Item 2, Chart 1. 2020, p. 25. Available online: https:/ /s2.q4cdn.com/056532643/files/doc_financials/2019/annual/Walmart-2019-AR-Final.pdf (accessed on 1 August 2021).

184. Chedraui. Closer to You: Annual Report 2017. Chedraui. 2017. Available online: http://grupochedraui.com.mx/wp-content/ themes /chedraui/documentos/informacion_financiera_ingles/informe_anual/Informe_Anual_2017_ENG.pdf (accessed on 1 August 2021).

185. Costco Wholesale. Kirkland Signature. Costco Wholesale. Available online: https://www.costco.com.mx/search/?text=kirkland (accessed on 1 August 2021).

186. IGD Retail Analysis. Latin America: Soriana in Focus. IGD Retail Analysis. 2015. Available online: https://retailanalysis.igd.com /news/news-article/t/latin-america-soriana-in-focus/i/9583 (accessed on 1 August 2021).

187. LaComer. Financial Information: Annual Reports. LaComer. 2019. Available online: http://lacomerfinanzas.com.mx/en/inform acion-financiera/informes-anuales/ (accessed on 1 August 2021).

188. Soriana. Soriana Reports Fourth Quarter and Full Year 2017 Financial Results. Soriana. 2017. Available online: http:/ /www.orga nizacionsoriana.com/pdf/reportes/2017/Eng-2018_02_23_Press_Release_4QFY2017.pdf (accessed on 1 August 2021).

189. United States. Mexico: Retail Foods 2018. Foreign Agricultural Service, US Department of Agriculture. 2018. Available online: https://apps.fas.usda.gov/newgainapi/api/report/downloadreportbyfilename?filename=Retail\%20Foods_Mexico\% 20City\%20ATO_Mexico_8-7-2018.pdf (accessed on 1 August 2021).

190. Conad. Annual Report 2018. Conad. 2018. Available online: https://en.calameo.com/read/0014568979599a14f561d (accessed on 1 August 2021).

191. Esselunga Group. Esselunga Group_Preliminary Results Full Year 2019. Esselunga Group. 2019. Available online: https:/ / www.esselunga.it/cms/investor-relations/press-releases/news/2019/26/esselunga-group--preliminary-results-fullyear-2018.html (accessed on 1 August 2021).

192. Esselunga Group. Esselunga Group Financial Statements Financial Year 2017. Esselunga. 2017. Available online: https: //www.esselunga.it/cms/info/investor-relations/financial-reports.html (accessed on 1 August 2021).

193. Italiani Coop. Rapporto Coop 2019 Versione Definitiva. Italiani Coop. 2019. Available online: https://www.italiani.coop/rappor to-coop-2019-versione-definitiva/ (accessed on 1 August 2021).

194. Italiani Coop. Punti Vendita. Italiani Coop. Available online: https://www.e-coop.it/punti-vendita (accessed on 1 August 2021).

195. Selex Gruppo Commerciale. Comunicati Stampa. Selex Gruppo Commerciale. 2020. Available online: https://www.selexgc.it/i t/comunicati-stampa (accessed on 1 August 2021).

196. Selex Gruppo Commerciale. Le Insegne del Gruppo. Selex Gruppo Commerciale. Available online: https://www.selexgc.it (accessed on 1 August 2021).

197. Ahold Delhaize. Product Innovation: Just-for-Kids Own-Brand Line Baunches in US Brands. Ahold Delhaize. 2019. Available online: https:/ / www.aholddelhaize.com/en/media/latest/media-releases/product-innovation-just-for-kids-own-brand-line -launches-in-us-brands/ (accessed on 1 August 2021). 
198. Albertsons. About Us-Own Brand. Alberstons. Available online: https://www.albertsons.com/about-us/own-brand-lp.html (accessed on 1 August 2021).

199. Kroger. Our Quality Brands. Kroger. Available online: https://www.kroger.com/b/ourbrands (accessed on 1 August 2021).

200. Walmart Inc. Great Value. Available online: https:/ /www.walmart.ca/en/great-value/N-1019684 (accessed on 1 August 2021).

201. Asda Group Ltd. Own Brands. Asda Group Ltd. Available online: https:/ /www.asda.com/about/own-brands (accessed on 1 August 2021).

202. Lidl GB. About Our Products. Lidl GB. Available online: https://www.lidl.co.uk/our-products (accessed on 1 August 2021).

203. Sainsbury's. Ranges. Sainsbury's. Available online: https://www.sainsburys.co.uk/webapp/wcs/stores/servlet/gb/grocerie s/get-ideas / our-ranges / our-ranges? storeId=10151\&langId=44\&krypto=\%2B3hQOfTNF0GfDlwFu\%2Ft $\% 2 B T 5 i L 7 C p u S 4 e o p$ DjwBMBK\%2FfVgaqjLHOc3rwNh27rStT0vIbW\%2F6mG54mdWIyrv9yuOZBJ5rq95L6DPJfOXaf8RucSObyIayI3K6PJhQ3QDB EL4gIYrwx\%2BqGONCWVukunnq9jgzUfsdc\%2Fo4ivU5P8VSwH0\%3D\&ddkey=https\%3Agb\%2Fgroceries \%2Fget-ideas \%2Fo ur-ranges\%2Four-ranges (accessed on 1 August 2021).

204. Waitrose. Discover Our Exclusives. Waitrose. Available online: https://www.waitrose.com/content/waitrose/en/home/inspir ation/about_waitrose/about_our_food/our_brands.html?wtrint=1-Content-_-2-About\%20Waitrose-_-3-Brandsandawards-_4--_-5-text-_-6-brands (accessed on 1 August 2021).

205. Auchan Retail. Auchan Annual Financial Report and non-Financial Performance Statement. Auchan Retail. 2020. Available online: https:/ /www.auchan-retail.com/en/financial-documents-2019/ (accessed on 1 August 2021).

206. Carrefour Group. Key Dates in Carrefour group's History. Carrefour. Available online: https://www.carrefour.com/en/group /history (accessed on 1 August 2021).

207. E.Leclerc. Marques. E.Leclerc. Available online: https:/ /www.e-leclerc.com/catalogue/marques-distributeurs (accessed on 1 August 2021).

208. Les Mousquetaires. Intermarché. Les Mousquetaires. Available online: https://www.mousquetaires.com/nos-enseignes/alimen taire/intermarche/ (accessed on 1 August 2021).

209. Système U. Toutes les Marques U. Système U. Available online: https://www.magasins-u.com/toutes-les-marques-u (accessed on 1 August 2021).

210. Coles Group. Pantry. Coles Group. Available online: https://shop.coles.com.au/a/national/everything/browse/pantry?page Number $=1$ (accessed on 1 August 2021).

211. IGA. Our Brands. IGA. Available online: https://www.iga.com.au/our-brands/ (accessed on 1 August 2021).

212. Woolworths Group. Our brands. Woolworths Group. Available online: https://www.woolworths.com.au/shop/discover/ourbrands (accessed on 1 August 2021).

213. Costco Wholesale. Kirkland Signature. Available online: https://www.costco.com/kirkland-signature.html (accessed on 1 August 2021).

214. Loblaw Companies Ltd. Home. Available online: https://www.loblaw.ca/en.html (accessed on 1 August 2021).

215. Metro. Our Products and Private Brands. Available online: https://www.metro.ca/en/our-products-private-brands (accessed on 1 August 2021).

216. Sobeys Corporate. Sobeys Private Label Offering. Available online: https://corporate.sobeys.com/our-brands/ (accessed on 1 August 2021).

217. Chedraui. Chedraui Monteblanco Selecto, Selecto Brand. Chedraui. Available online: https://www.chedraui.com.mx/Departam entos/Súper/c/MC21?q=\%3Arelevance\%3AspecialityCategories\%3AnuestrasMarcas\&toggleView=grid (accessed on 1 August 2021).

218. Walmart Inc. Great Value. Walmart Inc. Available online: https://www.walmart.com/search/?query=great\%20value (accessed on 1 August 2021).

219. Maruetsu. Happy Living: 2012 Corporate Profile. Maruetsu. 2012. Available online: https://www.maruetsu.co.jp/corporate/pdf /2012_kaishaannai_english.pdf (accessed on 1 August 2021).

220. Seijo Ishii. Philsophy: Quality Food for a Quality Life. Seijo Ishii. Available online: http://www.seijoishii.co.jp/en/about/ (accessed on 1 August 2021).

221. Aldi. Produkte: Unsere Eigenmarken. Aldi. Available online: https://www.aldi-nord.de/produkte/unsere-marken.html (accessed on 1 August 2021)

222. Metro. The Own Brands. Metro. Available online: https://www.metroag.de/en/brands/real (accessed on 1 August 2021).

223. Rewe. Die REWE Markenwelt-Nur das Beste fur Dich. Rewe. Available online: https://www.rewe.de/marken/ (accessed on 1 August 2021).

224. Albert Heijn. Belangrijke Informatie over Online Bestellen. Albert Heijn. Available online: https://www.ah.nl/producten (accessed on 1 August 2021).

225. Conad. Logo Rosso. Conad. Available online: https:/ / www.conad.it (accessed on 1 August 2021).

226. Gruppo VéGé. Home. Gruppo VéGé. Available online: https://www.gruppovege.it (accessed on 1 August 2021).

227. Gruppo VéGé. Prodotti VéGé. Gruppo VéGé. Available online: https:/ /www.gruppovege.it/prodotti/ (accessed on 1 August 2021).

228. Maurizio, C.; Silvia, C. Consumer stated preferences for dairy products with carbon footprint labels in Italy. Agric. Food Econ. 2020, 8, 4. [CrossRef] 
229. Selex Gruppo Commerciale. Le Nostre Marche. Selex. Available online: https:/ /www.famila.it/le-nostre-marche (accessed on 1 August 2021).

230. United States. Freight Rail Overview. Federal Railroad Administration, US Department of Transportation. 2019. Available online: https:/ / railroads.dot.gov/rail-network-development/freight-rail/freight-rail-overview (accessed on 1 August 2021).

231. United States. Number of U.S. Airports. Bureau of Transportation Statistics, US Department of Transportation. 2019. Available online: https: / / www.bts.gov/content/number-us-airportsa (accessed on 1 August 2021).

232. United States. Number of Stations Served by Amtrak and Rail Transit, Fiscal Year. Bureau of Transportation Statistics, US Department of Transportation. 2018. Available online: https://www.bts.gov/content/number-stations-served-amtrak-and-rail-t ransit-fiscal-year (accessed on 1 August 2021).

233. Canada. The Canadian Transportation System: Highway and Air Infrastructure. Statistics Canada. 2018. Available online: https://www144.statcan.gc.ca/tdih-cdit/cts-rtc-eng.htm (accessed on 1 August 2021).

234. Canada. Rail Transportation. Transport Canada. 2012. Available online: https://www.tc.gc.ca/eng/policy/anre-menu-3020.htm (accessed on 1 August 2021).

235. Dicex Integral Trade. Seaports and Their Role in Mexico. Dicex Integral Trade. 2019. Available online: https://dicex.com/en/sea ports-and-their-role-in-mexico/ (accessed on 1 August 2021).

236. Organization for Economic Co-Operation and Development. Frieght Railway Development in Mexico. Organization for Economic Co-Operation and Development. 2014. Available online: https://www.itf-oecd.org/sites/default/files/docs/14mexicorail.pdf (accessed on 1 August 2021).

237. Statistica. Number of Airports in Mexico from 1991 to 2018. Statistica. 2018. Available online: https://www.statista.com/statistic s/746907/mexico-number-of-airports / (accessed on 1 August 2021).

238. Italy. The New Italian Port System. Ministero delle Infrastrutture e dei Transporti. 2018. Available online: http:/ /www.mit.gov.it /en/comunicazione/news/porti/new-italian-port-system (accessed on 1 August 2021).

239. World Bank. Rail Lines (Total Route-km)_Italy. World Bank. 2018. Available online: https://data.worldbank.org/indicator/IS RRS.TOTL.KM?locations=IT (accessed on 1 August 2021).

240. Autralia. Designated International Airports in Australia. Department of Infrastructure, Transport, Regional Development and Communications. 2019. Available online: https://www.infrastructure.gov.au/aviation/international/icao/desig_airports.aspx (accessed on 1 August 2021).

241. World Bank. Rail Lines (Total Route-km)—Australia. World Bank. 2011. Available online: https://data.worldbank.org/indicator /IS.RRS.TOTL.KM?locations=AU (accessed on 1 August 2021).

242. World Bank. Rail Lines (Total Route-km)_France. World Bank. 2018. Available online: https://data.worldbank.org/indicator/I S.RRS.TOTL.KM?locations=FR (accessed on 1 August 2021).

243. World Bank. Rail Lines (Total Route-km)—Netherlands. World Bank. 2010. Available online: https://data.worldbank.org/indic ator/IS.RRS.TOTL.KM?locations=NL (accessed on 1 August 2021).

244. Maritime UK. Ports. Maritime UK. 2020. Available online: https://www.maritimeuk.org/about/our-sector/ports / (accessed on 1 August 2021).

245. United Kingdom. Airport Data (2018 01). UK Civil Aviation Authority. 2018. Available online: https://www.caa.co.uk/Data-and -analysis/UK-aviation-market/Airports/Datasets/UK-Airport-data/Airport-data-2018-01/ (accessed on 1 August 2021).

246. World Bank. Rail Lines (Total Route-km)—United Kindom. World Bank. 2018. Available online: https://data.worldbank.org/ind icator/IS.RRS.TOTL.KM?locations=GB (accessed on 1 August 2021).

247. Germany. Waterways as Transport Routes. Federal Ministry of Transport and Digital Infrastructure. 2020. Available online: https://www.bmvi.de/SharedDocs/EN/Articles/WS/waterways-as-transport-routes.html (accessed on 1 August 2021).

248. World Bank. Rail lines (Total Route-km)—Germany. World Bank. 2018. Available online: https://data.worldbank.org/indicator /IS.RRS.TOTL.KM?locations=DE (accessed on 1 August 2021).

249. Japan. Airports in Japan. Ministry of Land, Infrastructure, Transport and Tourism (MLIT). 2007. Available online: https: / / www.mlit.go.jp/koku/15_hf_000124.html (accessed on 1 August 2021).

250. Knoema. Japan-Total Route Rail Lines. Knoema. 2018. Available online: https://knoema.com/atlas/Japan/Length-of-rail-lines (accessed on 1 August 2021).

251. Sea Rates. Sea Ports of Japan. Sea Rates. 2020. Available online: https://www.searates.com/maritime/japan.html (accessed on 1 August 2021)

252. Canada. Fields of study. Job Bank. Available online: https://www.jobbank.gc.ca/career-planning/search-field-of-study (accessed on 1 August 2021).

253. Canada. Studying in Food Technology and Processing College/CEGEP (01.1002). Job Bank. Available online: https://www.jobb ank.gc.ca/studentdashboard/01.1002/LOS04 (accessed on 1 August 2021).

254. United States. Agriculture and Food Research Initiative: Education and Workforce Development. National Institute of Food and Agriculture (US Department of Agriculture). 2020. Available online: https://nifa.usda.gov/funding-opportunity/agriculture-an d-food-research-initiative-education-workforce-development (accessed on 1 August 2021).

255. United States. Indian and Native American Programs. U.S. Department of Labor. Available online: https://www.dol.gov/gene $\mathrm{ral} /$ topic/training/indianprograms (accessed on 1 August 2021). 
256. Australia. Student Payments. Study Assist. Available online: https://www.studyassist.gov.au/support-while-you-study/suppo rt-students (accessed on 1 August 2021).

257. Germany. The Cabinet Makes Social Cohesion and Modernisation Priorities. Federal Ministry of Finance. 2019. Available online: https://www.bundesfinanzministerium.de/Content/EN/Pressemitteilungen/2019/2019-03-20-pm-eckwertebeschlu ss.html;jsessionid=CDC6751A7635F121CC830AC0E68A7038.delivery2-replication (accessed on 1 August 2021).

258. Long, B.T. Addressing the Academic Barriers to Higher Education. 2014. Available online: https://vtechworks.lib.vt.edu/handle /10919/90811 (accessed on 1 August 2021).

259. Bryne, D.; McCoy, S. 'The sooner the better I could get out of there': Barriers to higher education in Ireland. Ir. Educ. Stud. 2011, 30, 141-157.

260. Career One Stop. Food Scientists and Technologists. Career One Stop. Available online: https://www.careeronestop.org/toolkit/ careers / occupations /Occupation-profile.aspx?keyword=Food\%20Scientists\%20and\%20Technologists\&onetcode=19101200\&l ocation=USA (accessed on 1 August 2021).

261. United Kingdom. Employment by Occupation. 2020. Available online: https:/ /www.ons.gov.uk/employmentandlabourmarket /peopleinwork/employmentandemployeetypes/datasets/employmentbyoccupationemp04 (accessed on 1 August 2021).

262. Italy. Employment Rate, Monthly Data. Italian National Institute of Statistics. Available online: http:/ / dati.istat.it/Index.aspx?Q ueryId=25132\&lang=en (accessed on 1 August 2021).

263. Italy. University Graduates-Occupational Status: Degree Group and Monthly Income. Italian National Institute of Statistics. Available online: http:/ / dati.istat.it/Index.aspx?QueryId=25981\&lang=en (accessed on 1 August 2021).

264. Mexico. Government of Mexico. Available online: http:/ /www.gob.mx/ (accessed on 1 August 2021).

265. Mexico. Secretaría de Educación Pública. Secretaría de Educación Pública. Available online: https://www.gob.mx/sep (accessed on 1 August 2021)

266. World Education News and Reviews. Education in Mexico. WENR. 2019. Available online: https://wenr.wes.org/2019/05/edu cation-in-mexico-2 (accessed on 1 August 2021).

267. Organization for Economic Co-Operation and Development. Average Wages: Total, US Dollars, 2018 or Latest Available. 2018. Available online: https:/ / data.oecd.org/earnwage/average-wages.htm\#indicator-chart (accessed on 1 August 2021).

268. United States. Unemployed Persons by Industry and Class of Worker, not Seasonally Adjusted (Table A-14.). U.S. Bureau of Labor Statistics. Available online: https:/ / www.bls.gov/news.release/empsit.t14.htm (accessed on 1 August 2021).

269. United Kingdom. EARN02: Average Weekly Earnings by Sector. Office for National Statistics. Available online: https://www.ons.gov.uk/employmentandlabourmarket/peopleinwork/earningsandworkinghours/datasets/averageweekly earningsbysectorearn02 (accessed on 1 August 2021).

270. Germany. Statistik: 62321. Federal Office of Statistics. 9 May 2020. Available online: https:/ /www-genesis.destatis.de/genesis/ online? operation=statistic\&levelindex=0\&levelid $=1589038252871 \&$ code $=62321$ (accessed on 1 August 2021).

271. Germany. Labour Market. Federal Office of Statistics. Available online: https://www.destatis.de/EN/Themes/Labour/LabourMarket/_node.html (accessed on 1 August 2021).

272. Germany. Employment. Federal Office of Statistics. Available online: https://www.destatis.de/EN/Themes/Labour/LabourMarket/Employment/_node.html (accessed on 1 August 2021).

273. Germany. Employees by Industries. Federal Office of Statistics. Available online: https://www.destatis.de/EN/Themes/Econ omy/Short-Term-Indicators/Long-Term-Series/Labour-Market/lrerw14a.html (accessed on 1 August 2021).

274. France. Monthly Wage Index-Manufacterer of Food Products, Beverage and Tobbaco. Institut National de la Statistique et des Études Économiques. 2017. Available online: https://www.insee.fr/en/statistiques/serie/010562699\#Tableau (accessed on 1 August 2021).

275. France. ILO Employed Persons (Employment Rate)—All—France Excluding Mayotte—SA Data (Series 010605852). National Institute of Statistics and Economic Studies. Available online: https://www.insee.fr/en/statistiques/serie/010605852\#Tableau (accessed on 1 August 2021).

276. France. Ministère Do L'éducation Nationale er de la Jeunesse. Ministère Do L'éducation Nationale Er de La Jeunesse. Available online: https: / / www.education.gouv.fr/ (accessed on 1 August 2021).

277. Italy. Average Hourly Earnings for Employee Jobs in the Private Sector: Level of Education. Italian National Institute of Statistics. Available online: http:/ / dati.istat.it/Index.aspx?QueryId=33475\&lang=en (accessed on 1 August 2021).

278. Netherlands. Employment; Sex, Type of Employment Contract, Job Characteristics, Cao-Sector. CBS Statistics Netherlands. 2019. Available online: https://opendata.cbs.nl/statline/\#/CBS/en/dataset/81463ENG/table?ts=1585336799099 (accessed on 1 August 2021).

279. Netherlands. International Visitor-DUO. Education Administration Service: Ministry of Education, Culture and Science. Available online: https:/ /www.duo.nl/particulier/international-visitor/index.jsp (accessed on 1 August 2021).

280. Netherlands. Monthly Labour Participation and Unemployment. CBS Statistics Netherlands. Available online: https://www.cbs. $\mathrm{nl} / \mathrm{en}-\mathrm{gb}$ / figures/detail/80590eng (accessed on 1 August 2021).

281. Japan. Employed Person by Industry and Occupation 2019 Average. 2019. Available online: https://www.e-stat.go.jp/en/stat-s earch $/$ files?page $=1 \&$ layout $=$ datalist $\&$ toukei $=00200531 \&$ tstat $=000000110001 \&$ cycle $=7 \& y e a r=20190 \&$ month $=0 \& t c l a s s 1=000001$ 040276\&tclass2 $=000001040283 \&$ tclass3 $=000001040284 \&$ result_back $=1$ (accessed on 1 August 2021). 
282. Australia. Average Weekly Earnings, Australia, Nov 2019 (6302.0). Australian Bureau of Statistics. 2019. Available online: https:/ / www.abs.gov.au/AUSSTATS/abs@.nsf/DetailsPage/6302.0Nov\%202019?OpenDocument (accessed on 1 August 2021).

283. Australia. Employment by Industry 2019. Parliament of Australia. Available online: https://www.aph.gov.au/About_Parliamen t/Parliamentary_Departments/Parliamentary_Library/FlagPost/2019/April/Employment-by-industry-2019 (accessed on 1 August 2021).

284. Australia. Australian Qualifications Framework (PDF File). Australian Qualifications Framework Council. Available online: https:/ / www.aqf.edu.au (accessed on 1 August 2021).

285. Japan. Higher Education in Japan (PDF file). 2013. Available online: https://www.mext.go.jp/en/policy/education/highered/ index.htm (accessed on 1 August 2021).

286. United Kingdom. What Can I Do with a Food Science Degree? Prospects. Available online: https://www.prospects.ac.uk/career s-advice/what-can-i-do-with-my-degree/food-science (accessed on 1 August 2021).

287. European Centre for the Development of Vocational Training. Apprenticeship Review: Italy. CEDEFOP. 2017. Available online: https:/ / www.cedefop.europa.eu/en/publications-and-resources/publications/4159 (accessed on 1 August 2021).

288. Netherlands. Continuing Vocational Training. CBS Statistics Netherlands. Available online: https://opendata.cbs.nl/statline/\# /CBS/en/dataset/81850ENG/table?ts=1585316843379 (accessed on 1 August 2021).

289. Ahmed, A.; Atif, M.; Hossain, M.; Mia, L. Do LGBT Diversity Policies Create Value for Firms? J. Bus. Ethics 2019, 167, 775-791.

290. Brimhall, K.C.; Mor Barak, M.E. The Critical Role of Workplace Inclusion in Fostering Innovation, Job Satisfaction, and Quality of Care in a Diverse Human Service Organization. Hum. Serv. Organ. Manag. Leadersh. Gov. 2018, 42, 474-492.

291. Díaz-García, C.; González-Moreno, A.; Sáez-Martínez, F.J. Gender Diversity within R\&D Teams: Its Impact on Radicalnes of Innovation. Innov. Manag. Policy Pract. 2013, 15, 149-160.

292. Australia. Distribution of Earnings for Employees by Industry (Table 3). Australian Bureau of Statistics. 2019. Available online: https:/ / www.abs.gov.au/AUSSTATS/abs@.nsf/DetailsPage/6333.0August\%202019?OpenDocument (accessed on 1 August 2021).

293. Australia. Median Earnings for Employees by Demographic Characteristics and Full-Time or Part-Time (Table 2). Australian Bureau of Statistics. 2019. Available online: https://www.abs.gov.au/AUSSTATS/abs@.nsf/DetailsPage/6333.0August\%202019 ?OpenDocument (accessed on 1 August 2021).

294. United Kingdom. Labour Market Status of Disabled People. Office for National Statistics. 2020. Available online: https://www.ons.gov.uk/employmentandlabourmarket/peopleinwork/employmentandemployeetypes/datasets/labourma rketstatusofdisabledpeoplea08 (accessed on 1 August 2021).

295. United Kingdom. Employment by Country of Birth and Nationality. Office for National Statistics. 2018. Available online: https:/ / www.ons.gov.uk/employmentandlabourmarket/peopleinwork/employmentandemployeetypes/datasets/empl oymentbycountryofbirthandnationalityemp06 (accessed on 1 August 2021).

296. Japan. Diversity. Available online: https://www.japan.go.jp/diversity/index.html (accessed on 1 August 2021).

297. Australia. Form of Employment by Industry, Occupation and Educational Qualification (Table 10). Australian Bureau of Statistics. 2019. Available online: https://www.abs.gov.au/AUSSTATS/abs@.nsf/DetailsPage/6333.0August\%202019?OpenDocument (accessed on 1 August 2021).

298. Japan. Labour Force Survey Basic Tabulation Statistical Table Whole Japan Yearly 2019. Portal Site of Official Statistics of Japan. Available online: https: / / www.e-stat.go.jp / en / stat-search / files?page $=1 \&$ layout=datalist \&toukei=00200531\&tstat=000000110001 \&cycle $=7 \&$ year $=20190 \&$ month $=0 \& t c l a s s 1=000001040276 \&$ tclass $2=000001040283 \&$ tclass $3=000001040284 \&$ result_back $=1$ (accessed on 1 August 2021).

299. Mexico. Employment and Occupation. National Institute of Statistics and Geography. 2006. Available online: http://en.www.ine gi.org.mx/temas/empleo/default.html\#Tabular_data (accessed on 1 August 2021).

300. Netherlands. Wealth of Households; Components of Wealth. CBS Statistics Netherlands. Available online: https://www.cbs.nl/e n-gb/figures/detail/83834ENG (accessed on 1 August 2021).

301. United Kingdom. Earnings and Working Hours. Office for National Statistics. Available online: https://www.ons.gov.uk/emplo ymentandlabourmarket/peopleinwork/earningsandworkinghours (accessed on 1 August 2021).

302. United States. USPTO Fee Schedule. United States Patent and Trademark Office. 2018. Available online: https://www.uspto.go v/learning-and-resources/fees-and-payment/uspto-fee-schedule (accessed on 1 August 2021).

303. United States. General Information Concerning Patents. United States Patent and Trademark Office. 2015. Available online: https: / / www.uspto.gov/patents-getting-started/general-information-concerning-patents\#heading-2 (accessed on 1 August 2021).

304. United States. Maintain Your Patent. United States Patent and Trademark Office. Available online: https://www.uspto.gov/pate nts-maintaining-patent/maintain-your-patent (accessed on 1 August 2021).

305. United States. Patent FAQs. United States Patent and Trademark Office. Available online: https://www.uspto.gov/help/patenthelp (accessed on 1 August 2021).

306. United States. Patent Process Overview. United States Patent and Trademark Office. Available online: https://www.uspto.gov/ patents-getting-started/patent-process-overview\#step3 (accessed on 1 August 2021).

307. Canada. Doing Business Abroad: Protecting Your IP in Mexico. Canadian Intellectual Property Office. 2020. Available online: https://www.ic.gc.ca/eic/site/cipointernet-internetopic.nsf/eng/wr04735.html (accessed on 1 August 2021). 
308. European Union. How to Register Your Patent in Mexico. Latin America IPR SME Helpdesk. 2017. Available online: https://ww w.latinamerica-ipr-helpdesk.eu/sites/default/files/factsheets/how_to_register_your_patent_mexico_edition.pdf (accessed on 1 August 2021).

309. Mexico. Instituto Mexicano de la Propiedad Industrial. Government of Mexico. Available online: https://www.gob.mx/impi (accessed on 1 August 2021).

310. Canada. A Guide to Patents. Canadian Intellectual Property Office. 2020. Available online: http://www.cipo.ic.gc.ca/eic/site/c ipoInternet-Internetopic.nsf/eng/h_wr03652.html\#marketingLicensingPatent1 (accessed on 1 August 2021).

311. Canada. Standard Fees for Patents. Canadian Intellectual Property Office. 2020. Available online: https://www.ic.gc.ca/eic/site/ cipointernet-internetopic.nsf/eng/wr00142.html (accessed on 1 August 2021).

312. Canada. Annual Report 2017-2019: Helping Make Canada a Global Centre for Innovation. Canadian Intellectual Property Office. 2019. Available online: https://www.ic.gc.ca/eic/site/cipointernet-internetopic.nsf/eng/h_wr04468.html (accessed on 1 August 2021).

313. Canada. How Your Patent Application is Processed. Canadian Intellectual Property Office. 2019. Available online: https: //www.ic.gc.ca/eic/site/ cipointernet-internetopic.nsf/eng/wr01414.html (accessed on 1 August 2021).

314. Canada. Tutorial-Your Patent Application. Canadian Intellectual Property Office. 2016. Available online: https://www.ic.gc.ca /eic/site/cipointernet-internetopic.nsf/eng/wr01398.html (accessed on 1 August 2021).

315. Canada. What Are Trademarks? Canadian Intellectual Property Office. 2016. Available online: https://www.ic.gc.ca/eic/site/ci pointernet-internetopic.nsf/eng/wr03718.html (accessed on 1 August 2021).

316. Lexis Halsbury's Laws of Canada. I. Patents of Invention, 1 Applicable Law, (2) Patent Act. 2020. Available online: https: / / advance.lexis.com/api/permalink/23e8fd96-e8fa-4c3b-935a-561fd48c8dbd/?context=1505209 (accessed on 1 August 2021).

317. United Kingdom. Guidance: Patent Fact Sheets. Intellectual Property Office. 2014. Available online: https://www.gov.uk/gover nment/publications/patent-fact-sheets (accessed on 1 August 2021).

318. Germany. Patent Fees. German Patent and Trade Mark Office. 2020. Available online: https://www.dpma.de/english/services/f ees/patents/index.html (accessed on 1 August 2021).

319. Germany. Patents: Examination and Grant. German Patent and Trade Mark Office. 2020. Available online: https://www.dpma.d e/english/patents/examination_and_grant/index.html (accessed on 1 August 2021).

320. Germany. Questions around Patents. German Patent and Trade Mark Office. 2020. Available online: https://www.dpma.de/en glish/patents/faq/index.html (accessed on 1 August 2021).

321. Netherlands. Fees (patents). Netherlands Enterprise Agency. Available online: https://english.rvo.nl/onderwerpen/innovativeenterprise/patents-other-ip-rights/patents/fees-patents (accessed on 1 August 2021).

322. Netherlands. How Can I Apply for a Patent? Governement of the Netherlands. Available online: https://www.government.nl/ topics/intellectual-property/question-and-answer/how-can-i-apply-for-a-patent (accessed on 1 August 2021).

323. Netherlands. Protection of Intellectual Proeprty and Trade Secrets. Government of the Netherlands. Available online: https: / / www.government.nl/topics/intellectual-property (accessed on 1 August 2021).

324. Italy. Brevetti per Invenzione Industrale. Ministero Dello Svluppo Economico. 2019. Available online: https://www.uibm.gov.it/ attachments/invenzionistruzioni.pdf (accessed on 1 August 2021).

325. Italy. Information Italian Patents. SID. Available online: http://www.sib.it/en/patents/inventions-insights/patents/italian-pate nts/ (accessed on 1 August 2021).

326. Japan. Preliminary Statistical Data on Applications, Requests and Registrations. Japan Patent Office. 2020. Available online: https://www.jpo.go.jp/e/resources/statistics/syutugan_toukei_sokuho/index.html (accessed on 1 August 2021).

327. Japan. Schedule of Fees. Japan Patent Office. 2020. Available online: https://www.jpo.go.jp/e/system/process/tesuryo/hyou. html (accessed on 1 August 2021).

328. Japan. Procedures for Obtaining a Patent Right. Japan Patent Office. 2019. Available online: https://www.jpo.go.jp/e/system/p atent/gaiyo/patent.html (accessed on 1 August 2021).

329. Japan. List of FAQs: Fees. Japan Patent Office. 2012. Available online: https://www.jpo.go.jp/e/faq/yokuaru/fees.html (accessed on 1 August 2021).

330. Japan. The Role of the Japan Patent Office. Japan Patent Office. 2011. Available online: https://www.jpo.go.jp/e/introduction/s oshiki/yakuwari.html (accessed on 1 August 2021).

331. Australia. Patent Time and Costs. IP Australia. 2020. Available online: https://www.ipaustralia.gov.au/patents/understanding -patents / time-and-costs (accessed on 1 August 2021).

332. Australia. Types of Patents. IP Australia. 2020. Available online: https://www.ipaustralia.gov.au/patents/understanding-paten ts/types-patents (accessed on 1 August 2021).

333. Australia. Single Examination Process for Australia and New Zealand. IP Australia \& New Zealand Intellectual Property Office. Available online: https://www.ipaustralia.gov.au/sites/default/files/integration_of_patent_examination.pdf?acsf_files_redirect (accessed on 1 August 2021).

334. France. Patent Database. Institut National de Proriété Industrielle (INPI). 2020. Available online: https://bases-brevets.inpi.fr/ en/home.html (accessed on 1 August 2021).

335. France. The French Patent System. Cabinet Beau de Loménie. 2017. Available online: http://www.bdl-ip.com/upload/Etudes /uk/french_patent_system.pdf (accessed on 1 August 2021). 
336. United Kingdom. Statutory Guidance: The Patents Act 1977. Intellectual Property Office. 2018. Available online: https: / / www.gov.uk/government/publications/the-patents-act-1977 (accessed on 1 August 2021).

337. United Kingdom. Intellectual Property Enterprise Court. HM Courts \& Tribunals Service. Available online: https://www.gov.uk / courts-tribunals/intellectual-property-enterprise-court (accessed on 1 August 2021).

338. United Kingdom. Intellectual Property: Law and Practice. United Kingdom Government. Available online: https://www.gov.uk /topic/intellectual-property/law-practice (accessed on 1 August 2021).

339. United Kingdom. Limitation Act (1980 c. 58). UK Legislation. Available online: http://www.legislation.gov.uk/ukpga/1980/58 (accessed on 1 August 2021)

340. Japan. Patent Act (Act No. 121 of April 13, 1959). Japanese Law Translation. 2006. Available online: http://www.japanese lawtranslation.go.jp $/ \mathrm{law} /$ detail $/$ ?printID $=\& \mathrm{ft}=1 \& \mathrm{co}=01 \& \mathrm{x}=32 \& \mathrm{y}=19 \& \mathrm{ky}=$ 特 $\quad$ 法 \&page $=10 \& \mathrm{id}=42 \& \mathrm{lvm}=\& \mathrm{re}=02 \& \mathrm{vm}=02$ (accessed on 1 August 2021).

341. Japan. Laws of Japan: Civil Code (Part I, Part II Chapter I, 1896-Act No 89 of 1896). AsianLii. Available online: http: //www.asianlii.org/jp/legis/laws/ccipici1896an89o1896346/ (accessed on 1 August 2021).

342. Okuyama, S.; Patent Infringement Litigation in Japan. Japan Patent Office. 2016. Available online: https://www.jpo.go.jp/e/ne ws/kokusai/developing/training/textbook/document/index/patent_infringement_litigation_in_japan_2016.pdf (accessed on 1 August 2021).

343. United States. The United States Code, Title 35 Patents. Office of the Law Revision Counsel. 2020. Available online: https: //uscode.house.gov/browse/prelim@title35/part3/chapter29\&edition=prelim (accessed on 1 August 2021).

344. ICLG. Mexico: Patents 2020. ICLG. 2020. Available online: https://iclg.com/practice-areas/patents-laws-and-regulations/mexic o (accessed on 1 August 2021).

345. Holden, J. Italy: Introduction to Intellectual Property Law in Italy. Mondaq. 2004. Available online: https://www.mondaq.com/i taly/Intellectual-Property/21161/Introduction-To-Intellectual-Property-Law-In-Italy (accessed on 1 August 2021).

346. ICLG. Italy: Litigation and Dispute Resolution 2020. ICLG. 2020. Available online: https://iclg.com/practice-areas/litigation-a nd-dispute-resolution-laws-and-regulations/italy (accessed on 1 August 2021).

347. Italy. Italian Code of Industrial Property (Legislative Decree No. 30 of 10 February 2005). LES Italy. 2013. Available online: https://www.wipo.int/edocs/lexdocs/laws/en/it/it204en.pdf (accessed on 1 August 2021).

348. Australia. IP Legislation. IP Australia. 2019. Available online: https://www.ipaustralia.gov.au/about-us/legislation/ip-legislati on (accessed on 1 August 2021).

349. Australia. Patents Act 1990 (No. 83). Federal Register of Legislation. Available online: https://www.legislation.gov.au/Details /C2020C00099 (accessed on 1 August 2021).

350. Germany. German Civil Code. Bundesministerium der Justiz und fur Verbraucherschutz. Available online: https://www.gesetz e-im-internet.de/englisch_bgb/englisch_bgb.html (accessed on 1 August 2021).

351. Germany. Patent Act. Bundesministerium der Justiz und fur Verbraucherschutz. Available online: http://www.gesetze-im-inter net.de/englisch_patg/englisch_patg.html\#p0387 (accessed on 1 August 2021).

352. Canada. Patent Act (RSC 1985, c. P-4). Department of Justice. 2020. Available online: https://laws-lois.justice.gc.ca/eng/acts/p -4/page-13.html\#h-412994 (accessed on 1 August 2021).

353. Canada. Protect Your Innovation. Canadian Intellectual Property Office. 2018. Available online: https://www.ic.gc.ca/eic/site/ cipointernet-internetopic.nsf/eng/wr03586.html (accessed on 1 August 2021).

354. Netherlands. Patent Act 1995. Netherlands Enterprise Agency. Available online: https://english.rvo.nl/topics/innovation/pat ents-other-ip-rights-topic/patent-law/patent-act-1995 (accessed on 1 August 2021).

355. Netherlands. Patent and Other IP Rights. Netherlands Enterprise Agency. Available online: https://english.rvo.nl/onderwerpen /innovative-enterprise/ patents-other-ip-rights (accessed on 1 August 2021).

356. Japan. Budget. Ministry of Finance, Japan. 2020. Available online: https://www.mof.go.jp/english/budget/budget/index.html (accessed on 1 August 2021).

357. Canada. Budget 2019 (Table A2.12, (6) Net Expenditure). Government of Canada. 2019. Available online: https: / / www.budget.gc.ca/2019/docs/plan/anx-02-en.html\#44-Reconciliation-of-Budget-2019-Expenses-with-2018--19-Mai n-Estimates-and-2019--20-Planned-Estimates (accessed on 1 August 2021).

358. Canada. Budget 2019: Investing in the Middle Class. Government of Canada. 2019. Available online: https://www.budget.gc.ca /2019/home-accueil-en.html (accessed on 1 August 2021).

359. Netherlands. Summary of the 2019 Budget Memorandum. Government of the Netherlands. 2018. Available online: https://www. government.nl/topics/budget-day/documents/budgets/2018/09/18/summary-of-the-2019-budget-memorandum (accessed on 1 August 2021).

360. United States. Budget of the US Government. United States Government. 2019. Available online: https://www.usa.gov/budget (accessed on 1 August 2021).

361. United States. Spending Explorer. USA Spending. 2019. Available online: https://www.usaspending.gov/\#/explorer/budget_ function (accessed on 1 August 2021).

362. United Kingdom. Policy Paper, Budget 2018: Documents. HM Treasury \& Rt Hon Philip Hammond. 2018. Available online: https:/ / www.gov.uk/government/publications/budget-2018-documents (accessed on 1 August 2021). 
363. Australia. Budget 2019-20: Overview. Government of Australia. 2019. Available online: https://budget.gov.au/2019-20/conten t/overview.htm (accessed on 1 August 2021).

364. Australia. Budget Papers. Australian Government. 2019. Available online: https://budget.gov.au/2019-20/content/documents. htm (accessed on 1 August 2021).

365. Organization for Economic Co-Operation and Development. Open Government Data in Mexico: The Way Forward. Organization for Economic Co-Operation and Development. 2018. Available online: https://www.oecd.org/gov/open-government-data-in -mexico-9789264297944-en.htm (accessed on 1 August 2021).

366. United Kingdom. Guidance: National Data Strategy. Department for Digital, Culture, Media \& Sport. 2019. Available online: https:/ /www.gov.uk/guidance/national-data-strategy\#what-happens-next (accessed on 1 August 2021).

367. European Data Portal. Analytical Report 13: Open Data Best Practices in Europe's Top Three Performers: Ireland, Spain and France. European Data Portal. 2019. Available online: https://www.europeandataportal.eu/sites/default/files/analytical_repo rt_13_open-data-best-practices-top-performers.pdf (accessed on 1 August 2021).

368. France. Openness of Public Data. Gouvernement de France. 2016. Available online: https://www.gouvernement.fr/en/opennes s-of-public-data (accessed on 1 August 2021).

369. France. Public Data Policy. Gouvernement de France. 2014. Available online: https://www.gouvernement.fr/en/public-data-p olicy (accessed on 1 August 2021).

370. Open Government Partnership. Open Government Partnership: Summit Agenda. Open Government Partnership. 2015. Available online: https: / / www.opengovpartnership.org/documents/download-the-agenda-in-word/ (accessed on 1 August 2021).

371. Japan. Japan Open Data Charter Action Plan. Prime Minister of Japan and Cabinet. 2013. Available online: https://japan.kantei .go.jp/policy/it/2013/1029_fulltext.pdf (accessed on 1 August 2021).

372. Japan. Open Government Data Strategy. IT Strategic Headquarters. 2012. Available online: https://japan.kantei.go.jp/policy/it /20120704/text.pdf (accessed on 1 August 2021).

373. Germany. Cabinet retreat in Meseberg: German Government Forges Ahead with Digitalisation. Federal Government of Germany 2019. Available online: https://www.bundesregierung.de/breg-en/news/digital-klausur-meseberg-1694800 (accessed on 1 August 2021).

374. Canada. Open data. Government of Canada. 2020. Available online: https://open.canada.ca/en/open-data (accessed on 1 August 2021).

375. Canada. Canada's Digital Charter: Trust in a Digital World. Innovation, Science, and Economic Development Canada. 2019. Available online: https://www.ic.gc.ca/eic/site/062.nsf/eng/h_00108.html (accessed on 1 August 2021).

376. Canada. Report to the Clerk of the Privy Council: A Data Strategy Roadmap for the Federal Public Service. Privy Council Office. 2019. Available online: https:/ / www.canada.ca/en/privy-council/corporate/clerk/publications/data-strategy.html (accessed on 1 August 2021).

377. United States. 2020 Action Plan: Federal Data Strategy: Leveraging Data as a Strategic Asset. Offices of Management and Budget, Science and Technology Policy, Department of Commerce and Small Business Administration. 2019. Available online: https:/ / strategy.data.gov/action-plan/ (accessed on 1 August 2021).

378. Netherlands. Data Agenda Government. Digital Government. 2019. Available online: https://www.nldigitalgovernment.nl/doc ument/data-agenda-government/ (accessed on 1 August 2021).

379. Netherlands. Dutch Vision on Data Sharing between Businesses. Government of the Netherlands. 2019. Available online: https:/ / www.government.nl/ministries/ministry-of-economic-affairs-and-climate-policy/documents/reports/2019/02 /01/dutch-vision-on-data-sharing-between-businesses (accessed on 1 August 2021).

380. Australia. Review of Australian Government Data Activities 2018. Department of the Prime Minister and Cabinet. 2018. Available online: https:/ / www.pmc.gov.au/resource-centre/public-data/review-australian-government-data-activities-2018 (accessed on 1 August 2021).

381. Australia. Australian Government Public Data Policy Statement. Department of the Prime Minister and Cabinet. 2015. Available online: https:/ / www.pmc.gov.au/resource-centre/public-data/australian-government-public-data-policy-statement (accessed on 1 August 2021).

382. Australia. Public Data. Department of the Prime Minister and Cabinet. Available online: https://www.pmc.gov.au/public-data (accessed on 1 August 2021).

383. Canada. Personal Information Protection and Electronic Documents (Act SC 2000, c. 5.). Department of Justice. 2020. Available online: https:/ /laws-lois.justice.gc.ca/ENG/ACTS/P-8.6/index.html (accessed on 1 August 2021).

384. Canada. Privacy act RSC 1985, c. P-21. Department of Justice. 2020. Available online: https://laws-lois.justice.gc.ca/ENG/ACTS /P-21/index.html (accessed on 1 August 2021).

385. Canada. Summary of Privacy Laws in Canada. Office of the Privacy Commissioner of Canada. 2018. Available online: https:/ / www.priv.gc.ca/en/privacy-topics/privacy-laws-in-canada/02_05_d_15/ (accessed on 1 August 2021).

386. United Kingdom. Data Protection Act (2018, c 12). UK Legislation (Government). 2018. Available online: http://www.legislation gov.uk/ukpga/2018/12/contents/enacted (accessed on 1 August 2021).

387. United Kingdom. Data protection. UK Government. Available online: https://www.gov.uk/data-protection (accessed on 1 August 2021).

388. United Kingdom. Home. Information Commissioner's Office. Available online: https://ico.org.uk (accessed on 1 August 2021) 
389. France. Data Processing, Data Files and Individual Liberties: France (Act n $78-17$ of 6 January 1978). European Union Agency for Fundamental Rights. Available online: https: / fra.europa.eu/en/law-reference/act-ndeg78-17-6-january-1978-data-processingdata-files-and-individual-liberties (accessed on 1 August 2021).

390. United States. Online Privacy Law: France. The Library of Congress. 2017. Available online: https://www.loc.gov/law/help/o nline-privacy-law/2012/france.php (accessed on 1 August 2021).

391. Netherlands. Protection of Personal Data. Business Netherlands. Available online: https://business.gov.nl/regulation/protectio n-personal-data/ (accessed on 1 August 2021).

392. Japan. Laws and Policies: Act on the Protection of Personal Information. Personal Information Protection Commission Japan. 2017. Available online: https://www.ppc.go.jp/en/legal/ (accessed on 1 August 2021).

393. Japan. Current Legal Framework of the Protection of Personal Information. Personal Information Protection Commission Japan. 2015. Available online: https://www.ppc.go.jp/files/pdf/280222_Current_Legal_Framework_v2.pdf (accessed on 1 August 2021).

394. DLA Piper. Data Protection Laws of the World: Mexico. DLA Piper. 2019. Available online: https://www.dlapiperdataprotection .com/index.html? $\mathrm{t}=$ law \&c=MX (accessed on 1 August 2021).

395. Australia. Australian Information Commissioner and Privacy Commissioner. Office of the Australian Information Commissioner. 2020. Available online: https:/ / www.oaic.gov.au (accessed on 1 August 2021).

396. Australia. Privacy Act 1988. Federal Register of Legislation. Available online: https://www.legislation.gov.au/Series/C2004A03 712 (accessed on 1 August 2021).

397. Australia. Read the Australian Privacy Principles. Office of the Australian Information Commissioner. Available online: https:/ / www.oaic.gov.au/privacy/australian-privacy-principles/read-the-australian-privacy-principles/ (accessed on 1 August 2021). 